\title{
An Evidence Based Web Intervention to Facilitate Nurse Practitioner Participation in the Policy Making Process Related to Scope of Practice
}

Toni DiChiacchio

West Virginia University

Follow this and additional works at: https://researchrepository.wvu.edu/etd

\section{Recommended Citation \\ DiChiacchio, Toni, "An Evidence Based Web Intervention to Facilitate Nurse Practitioner Participation in the Policy Making Process Related to Scope of Practice" (2014). Graduate Theses, Dissertations, and Problem Reports. 140.}

https://researchrepository.wvu.edu/etd/140

This Dissertation is protected by copyright and/or related rights. It has been brought to you by the The Research Repository @ WVU with permission from the rights-holder(s). You are free to use this Dissertation in any way that is permitted by the copyright and related rights legislation that applies to your use. For other uses you must obtain permission from the rights-holder(s) directly, unless additional rights are indicated by a Creative Commons license in the record and/ or on the work itself. This Dissertation has been accepted for inclusion in WVU Graduate Theses, Dissertations, and Problem Reports collection by an authorized administrator of The Research Repository @ WVU.

For more information, please contact researchrepository@mail.wvu.edu. 
An Evidence Based Web Intervention to Facilitate Nurse Practitioner Participation in the Policy Making Process Related to Scope of Practice

\title{
Toni DiChiacchio
}

Doctoral Research Project submitted

to the School of Nursing at West Virginia University

\author{
in partial fulfillment of the requirements for the degree of \\ Doctor of Nursing Practice \\ Cynthia Persily, Ph.D., Chair \\ Andrea Brassard, Ph.D. \\ Aila Accad, MSN \\ Department of Nursing
}

\author{
Morgantown, West Virginia \\ 2014
}

Key words: nursing policy, full practice authority, advanced practice registered nurses (APRNs), political involvement Copyright 2014, Toni DiChiacchio 


\begin{abstract}
Intervention to Facilitate Nurse Practitioner Participation in the Policy Making Process Related to Scope of Practice
\end{abstract}

Toni DiChiacchio

Historically nurses have been strongly engaged in the political process, however in recent decades the profession has moved away from the policy arena. Without political engagement, issues that are important to the nursing profession are not addressed timely, if at all. One such issue is that of full practice authority for advanced practice registered nurses (APRNs). Well over 100 studies have been completed over the past 40 years showing the safe and quality care APRNs provide independently. Numerous well-respected, non-nursing organizations support the removal of state laws that impede the ability of APRNs to practice to the full extent of their education and training, particularly in light of the looming extinction of primary care physicians and the simultaneous increase in demand for primary care services (American Association of Retired People, 2011; Federal Trade Commission, 2012; Institute of Medicine, 2010; National Governor's Association, 2012). The purpose of this capstone project was to provide a website in which APRNs and APRN students could communicate quality information to legislators in support of full practice for APRNs in West Virginia during a legislative session in which a full practice bill was introduced. Website visitors who were APRNs or APRN students were asked to complete a survey on the website comparing their communication with legislators last year to their communication or intended communication, after they had been introduced to the website, during the current session. Findings included a strong statistical association between use of the website and communication with legislators along with a statistical association between use of the website and conveyance of quality information supporting full practice authority. The findings suggest that websites related to specific nursing issues could be a method to increase political involvement of nurses. 
Table of Contents

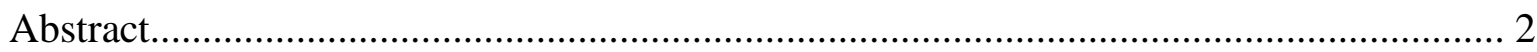

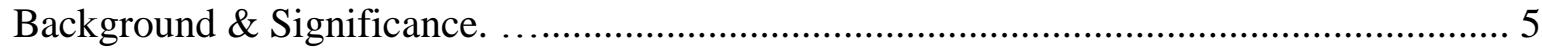

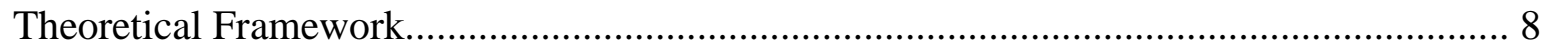

Project Description.................................................... 12

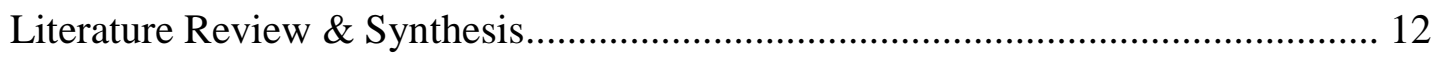

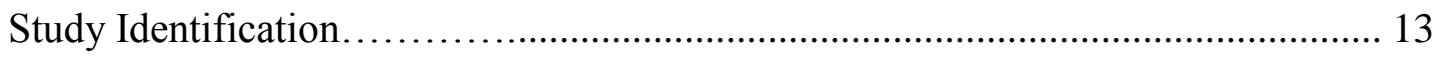

Organizational Congruence to Project..................................... 18

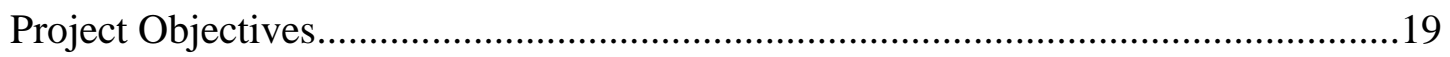

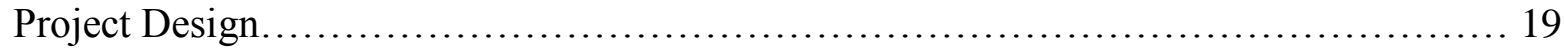

Evidence Based Intervention ..................................................................... 19

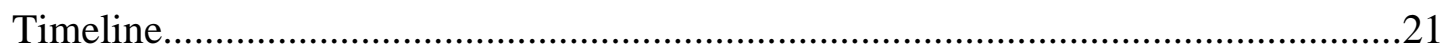

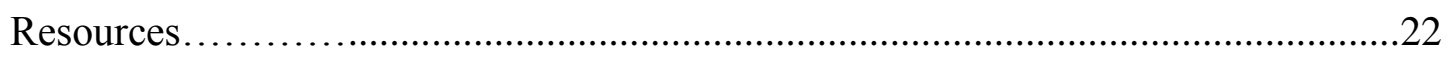

Project Results ............................................................................... 24

Data Analysis....................................................... 24

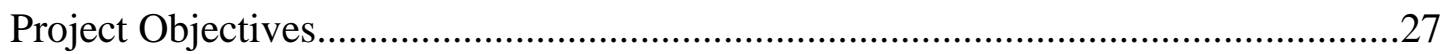

Unintended Consequences.............................................29

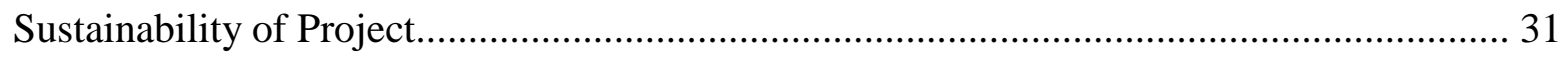

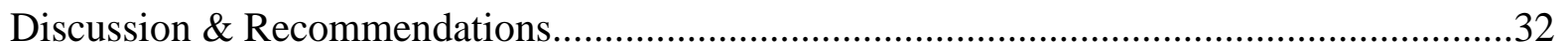

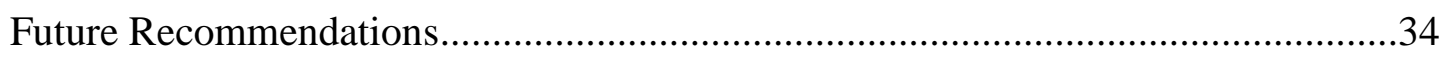

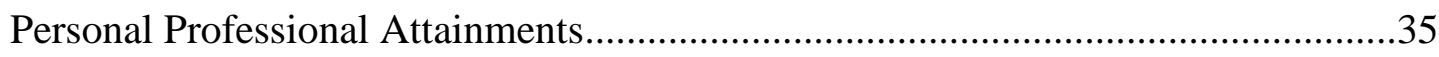

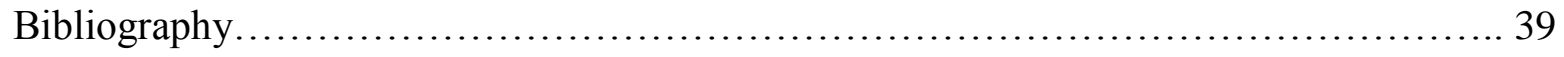

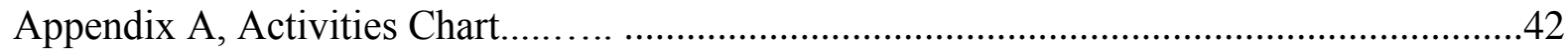

Appendix B, Timeline...................................................... 43 


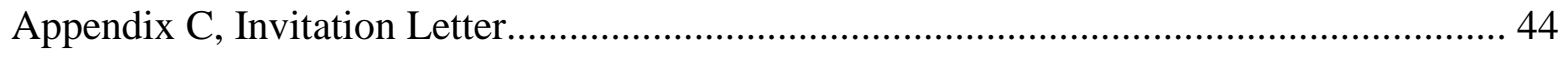

Appendix D, Project Budget.............................................. 45

Appendix E, Website Screen Shots......................................................... 46

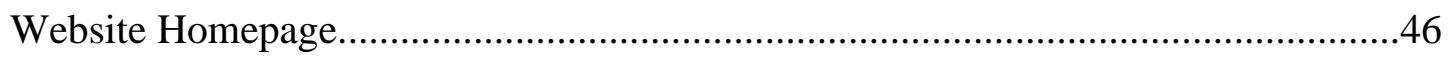

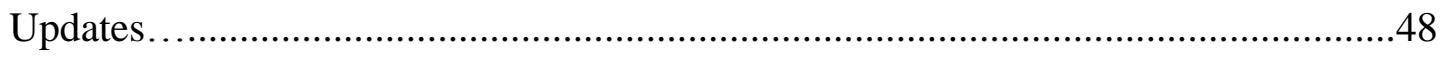

Research............................................................ 52

State Statutes....................................................67

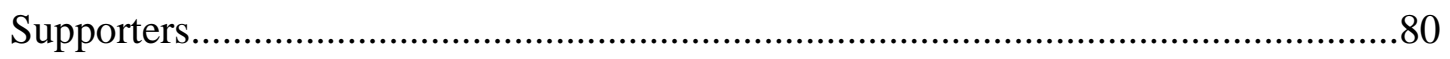

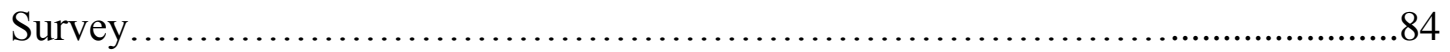

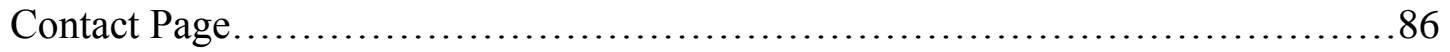




\section{Background and Significance}

Nurse practitioners (NPs) across the United States practice, based upon state law, under significantly different regulations. Nineteen states and the District of Columbia allow full practice authority for NPs (American Academy of Nurse Practitioners, 2013). The remaining states vary from minimal practice restrictions, such as naming a physician one would consult with if needed, to extremely restrictive, such as the inability to practice nor prescribe without physician direction (American Academy of Nurse Practitioners, 2013). The result is an underutilization of NPs capabilities in healthcare. The residents of states where NP's do not have full practice authority suffer from such limitations. In light of the national shortage of primary care physicians, the restrictions placed on NPs could be detrimental to patients' access to care (Fairman, Rowe, Hassmiller, \& Shalala, 2011). The Affordable Care Act, which expands health insurance access to Americans, is likely to make the primary care shortage more pronounced (Fairman, Rowe, Hassmiller, \& Shalala, 2011). States that have more restrictive practice regulations are at risk of losing their most talented NPs who may seek the professional setting of states where they can practice to the full extent to which they were trained. Additionally residents of states where limitations to full practice apply are essentially short-changed financially. For example, in WV, most NPs studied at a state funded college or university. Thus public funds are used to teach NP students who are educated to perform with full practice authority. With the current legal limitations placed on NPs in WV, the WV taxpayers are not able to access all the services that NPs were trained to provide despite the training being funded, in part, by their tax dollars. 
Over forty years of research on the quality of care provided by, and patients' satisfaction with, NPs' practice has shown outcomes and satisfaction at least equivalent to that of physicians (Anderer, 2008; Bakerjian, 2008; Bevis, et al., 2008; Coddington, Sands, Edwards, Kirkpatrick, \& Chen, 2011; Conlon, 2010; Dulisse \& Cromwell, 2010; Guzik, Menzel, Fitzpatrick, \& McNulty, 2009; Institute of Medicine, 2010; Laurant, et al., 2007; Lenz, Mundinger, Kane, \& Hopkins, 2004; Mundinger, et al., 2000; National Governor's Association, 2012; Newhouse, 2011; Pinkerton \& Bush, 2000; Wright, Romboli, DiTulio, Wogen, \& Belletti, 2011). In fact, several studies have shown that patient outcomes related to chronic diseases such as diabetes are better when NPs are involved in care (Conlon, 2010; Jackson, Lee, Edelman, Weinberger, \& Yano, 2010; Litaker, et al., 2003 ). West Virginia rates near the bottom in most health outcome categories, including lung disease, diabetes, obesity, and heart disease (West Virginia Department of Health \& Human Resources, 2012). Removing barriers to practice for NPs in WV could serve as a catalyst for improving the health of the state.

The majority of WV has been shown to be medically under-served areas (MUA) and/or health provider shortage areas (HPSA) by the federal government (US Department of Health \& Human Resources, 2013). This is in large part due to the rural nature of WV. Evidence shows states with full practice authority for NPs have larger percentages of NPs practicing in rural areas as compared to states with more restrictive practice legislation (Golden, 2012). Thus removing legislation restrictions may serve to increase the percentage of NPs practicing in rural communities in WV, improving access to care for those residents.

In addition to limiting the positive impact NP care could have on the residents of WV, the underutilization of NPs ability to provide healthcare based upon their training and education is detrimental to the nursing profession in WV. It is difficult to educate potential patients about 
what a NP is and what they can do when there is no consistency state to state on how an NP can practice. A similar challenge exists in recruiting nurses to further their education and become NPs; for those who reside in a practice restrictive state who have no ability or desire to move, the value of obtaining such training when it cannot be fully used may be questioned. Additionally, talented NPs who may consider moving to WV may be dissuaded by the practice limitations, particularly if they come from full practice authority states.

In October, 2010, The Future of Nursing report was released by the Institute of Medicine in cooperation with the Robert Wood Johnson Foundation (Institute of Medicine, 2010). This report had several policy recommendations addressing how the profession of nursing should be best used in order to care for the health of the nation. Key among those recommendations was assuring that states amend their laws related to advanced practice nursing so as not to hamper full practice authority (Institute of Medicine, 2010). Since that time there have been a number of other well respected non-nursing groups and organizations that have supported such action including such influential groups as The National Governors Association, the AARP, and the Federal Trade Commission (AARP, 2011; Federal Trade Commission, 2012; National Governor's Association, 2012).

The time was ripe for a tool to be developed for the APRNs of WV to utilize to be more involved in the political process. This tool was intended to allow NPs to efficiently and thoroughly provide education to their elected legislators about the benefits of amending current law restricting the practice of APRNs. Many nurses have no experience participating in the legislative process, and lack access to consistent, quality information to provide to legislators that could influence policy relative to APRN practice. The project involved the development of a website that contained information on practice authority law for APRNs throughout the country, 
research on care and outcomes provided by APRNs, documentation of support for full practice authority for APRNs from various organizations and groups, and simple methods APRNs in WV can utilize to interact with their respective state legislators to share the aforementioned information and support change in WV law to allow full APRN practice authority. The website was broadly marketed to APRNs in the state, and their interaction with the legislative process before and after using the website was evaluated.

\section{Theoretical Framework}

The ultimate goal of the project was to influence West Virginia legislators to amend current law to allow for full practice authority for nurse practitioners in the state. Political involvement of individual APRNs is requisite to influence this type of legislation. The means to achieve political involvement was at the heart of the proposed project; to provide an easy method for APRNs in the state to educate themselves and their respective elected legislators on the safe care APRNs provide and the positive impact this group of providers will have on the health of West Virginians.

John Kotter's model for leading change was utilized in designing this project. Kotter's model was developed in the mid-1990s as a business model for getting organizational change successfully assimilated into the business culture (Kotter, 2012). The business world during this

period was ripe with corporate takeovers, mergers \& acquisitions, and regulatory crack-downs on various industries (Kotter, 2012). Change became a constant in business and Kotter's model resonated with industry leaders as a viable method to assure adoption of desired changes (Kotter, 2012).

Kotter analyzed businesses in which change was attempted but failed and identified reasons for such failures. Once these failings were identified, he developed a framework of 
antonyms to those failures. His framework basically recommends doing the opposite of what has been done in the past at failing organizations, specifically, providing the following 8 steps for successfully achieving change: 1) create a sense of urgency 2) form a coalition 3) create a vision for change 4) communicate the vision 5) empower others to act on the vision 6) create short term wins 7) consolidate improvements and create more change 8) anchor the change (Kotter, 2012). These eight steps were utilized in the creation of this project plan.

When a change in behavior or process is proposed, emotional responses are likely to occur. Negative emotions like complacency, pessimism, insecurity and anger can easily derail a proposed or recommended change (Campbell, 2008). Kotter recognized this risk and to mitigate it, he recommended "creating a sense of urgency" as the first step to proposed change. This involves tapping into emotion to compel change. Emotion, rather than analysis, is typically a more pronounced and longer sustained motivator (Campbell, 2008). Rather than allowing negative emotions to destroy change proposals, associating change with some emotional favorability creates an environment that welcomes the proposed change. While the desire to ascertain full practice authority for APRNs is not new in WV, the setting in which we find ourselves is unique. The Affordable Care Act, which will provide an additional 125,000 WV residents with Medicaid beginning in January of 2014, creates a pressing environment that compels change due to its urgency. The majority of the state of WV is already either or both a medically underserved area (MUA) and a health provider shortage area (HPSA) (US Department of Health \& Human Resources, 2013). New Medicaid patients will put a sizeable strain on the already deficient primary care setting in WV creating a sense of urgency for this project.

Building a coalition to assist with advancing the change is paramount to its ultimate adoption. The intent of this project is to form a coalition of WV nurses, specifically APRNs, who 
have the tools to create change through the legislative process. There are many nursing professional organizations but only one that encompasses all nurses, regardless of specialty, practice area, or education level. The American Nurses Association (ANA) is the largest professional nursing organization in the country (American Nurses Association, 2013). The ANA has state contingencies which represent the interests of nursing in each state. The West Virginia Nurses Association (WVNA) is a natural partner in this project and was a large part of the coalition development. While only a minority of nurses in WV belong to the WVNA, it is still the largest singular membership organization to which WV nurses belong. In addition to partnering with the WVNA to connect with advanced practice nurses, a list of APRNs, including addresses, was also purchased from the West Virginia Board of Professional Nurses (WVBON). Traditional mail was used for the initial contact with APRNs introducing them to the website (Appendix C). A disclaimer was shared that the information collected would not be sold or shared for any other purpose than the proposed project. In addition, the letter was to be published in the WV Nurse publication inviting participants. Besides the WV Nurse publication, which is mailed to all nurses in the state, there was no other specific way to introduce APRN students to the project although word of mouth did play a small part as the instructor for the MSN Policy class at WVU shared the link with the students in that class.

Being visionary is a trait that differentiates leadership from management (Kouzes \& Posner, 2012). Developing, effectively communicating, and empowering others to share the vision of what the proposed change will achieve is the third, fourth and fifth steps in Kotter's change management theory. The vision created for this project rested upon sharing the benefits WV would receive by achieving congruence between how an APRN can practice in this state, with how they are educated and trained. To communicate this vision, the project included a 
letter that was sent out to APRNs in WV that contained a brief synopsis of what was available on the website and a description of how nurses have lacked involvement in the political process (Appendix C). The letter referred APRNs to visit the website which gave complete information. To empower sharing the vision, visitors to the website were able, if desired, to easily communicate with WV lawmakers to advocate for full practice authority for APRNs in WV and to refer the lawmakers to the site for full, factual, information on the issue.

Creating short term wins is Kotter's sixth step for successful change. The kind of short term win Kotter's describes is visible, unambiguous and related to the change (Kotter, 2012). Kotter's argument for reporting short term wins is to show how changes and sacrifices have a positive impact, to decrease cynicism, and to build momentum (Kotter, 2012). For this project, a page on the website contained a section that reported the latest updates on APRN practice legislation in WV. On this page, information such as when a full practice authority bill was submitted to the legislature, what lawmakers sponsored the legislation, quotes lawmakers shared regarding their support, and how the bill moved through the legislative process was reported. The information shared represented any and all forward motion on the issue of full practice authority, regardless of how small or inconsequential it seemed, as a short term win. Short term wins were also shared via Twitter and Facebook. Accounts in these social media sites were set up to easily and quickly communicate with APRNs.

Consolidating gains and producing more change is Kotter's seventh step. Kotter states in "Leading Change" that a cardinal rule is "whenever you let up before the job is done, critical momentum can be lost and regression may follow." (2012). So while informing of small wins during attempted change is important, it is just as important to not allow apathy to set in and inactivity of the coalition to follow. To counteract that possibility in the proposed project, the 
website home page, in addition to reporting the aforementioned small wins, also ended with a statement addressing the need to continue the work to achieve full practice authority. Periodic idioms encouraging political action were also sent out via Twitter and Facebook.

The final step of Kotter's change theory is to anchor change. A goal of this project was to encourage engagement of APRNs in the political process. Making that engagement simple, and arming WV APRNs with specific language and data to share with lawmakers, was intended to empower them to continue to be involved in the development of future health policy. After completion of the project a statement was be placed on the website, Facebook page, and Twitter, thanking participants for their involvement in the project, summarizing the success achieved related to the issue of full practice authority, and encouraging them to continue with healthcare policy development. Additionally, while this project was tested in $\mathrm{WV}$, because it proved successful, there is potential to expand the project to other states that do not allow APRNs to practice to the extent of their training and education.

\section{Project Description}

\section{Literature Review and Synthesis}

Literature reviews were conducted on two separate topics related to this project. The topics reviewed were the safety and quality of nurse practitioner care and the political involvement of nurses. The three databases searched for the care provided by nurse practitioners were CINAHL, Cochrane and Medline. The search terms utilized for CINAHL and Medline were "nurse practitioner", "physician”, and “outcome”; for Cochrane, “nurse practitioner" and "physician". In the Cochrane database, only reviews were selected, of which there were six. For CINAHL, other limitations were work published in 1998 or after, in the English language, in the United States geographic subset, and the search terms were limited to being found in the 
abstracts. This produced 29 results. Likewise in Medline, works published in or after 1998 in the English language, and with search terms found in abstracts were selected and resulted in 66 documents.

In addition to the database search, the other research analyzed included the works cited in the literature review section of the National Governor's Association White Paper entitled "The Role of Nurse Practitioners in Meeting Increasing Demands for Primary Care Services". The literature review outlined in that paper, which required empirical studies or meta-analysis, resulted in 22 articles. Naturally there was an element of duplication between the research in the paper and the findings of the database searches which provided an assurance that the breadth and completeness of the search was adequate.

\section{Study Identification}

Each of the articles identified were reviewed. Only documents which were systematic reviews or research were ultimately included in the analysis. Exclusion criteria included research done in countries other than the United States, studies in which APRNs worked under the direction or collaboration with physicians, and studies conducted before 1998.

Ultimately ten articles met criteria for inclusion which included two systematic reviews (Laurant, et al., 2007; Newhouse et al., 2011), two randomized control trials (Mundinger, et al., 2000; Lenz, Mundinger, Kane, \& Hopkins, 2004), and six descriptive comparative studies (Bevis, et al., 2008; Condosta, 2012; Conlon, 2010; Guzik, Menzel, Fitzpatrick, \& McNulty, 2009; Pinkerton \& Bush, 2000; Wright, Romboli, DiTulio, Wogen, \& Belletti, 2011). The Cochrane systematic review, Substitution of Doctors by Nurses (2007), looked at research published from 1966 through 2002. It included 13 randomized control studies and three before \& after studies. Three specific areas were pursued in the review including patient outcomes, care 
processes, and resource utilization. Patient outcomes included data on morbidity, mortality, patient satisfaction, compliance and preferences. Care processes included the following of clinical guidelines, standards of care and provider health activities, such as education. Resource utilization looked at length of visits, number of return visits, amount of ER and inpatient visits, lab \& imaging studies, and specialty referrals. The evidence from the review was homogenous, finding nurse practitioners' care is at a minimum, equivalent of that of physicians with at least equivalent patient satisfaction.

The second systematic review, "APN Outcomes" (2011) looked at all APRNs, rather than just NPs. Certified nurse midwives, nurse practitioners, and clinical nurse specialist were included. Attempts were made to collect research on certified registered nurse anesthetist but the authors could not find pertinent research on these nurses. The search was limited to research published from 1990 through 2008. Twenty randomized control trials and 49 observational comparative studies were found and reported upon. Various patient outcomes of the different APRNs were compared to their respective physician counterparts. Again, the results were homogenous with APRN patients having outcomes at least equivalent to physicians.

The two randomized controlled studies found in the literature search for this project were actually the same population but over different time frames. The first covered patient outcomes at six months and one year (Mundinger, et al., 2000). The second looked at outcomes at two years (Lenz, Mundinger, Kane, \& Hopkins, 2004). The researchers responsible for these studies made it a significant point to assure NPs had equal autonomy and responsibility as the physicians in the study. The research compared health status, disease specific physiological measures, satisfaction and specialist, ER or inpatient visits of patients. Once again, the practice of APRNs and physicians was equivalent. 
The six observational descriptive studies looked at different aspects of care, comparing APRNs to physicians in interventions and outcomes. One study compared trauma surgeons' ability to place tube thoracotomies to that of APRNs (Bevis, et al., 2008). No difference was noted between the two. There were two studies related to diabetic patients. The first compared hemoglobin A1Cs, glucose, weight, blood pressure and diabetic education between APRNs and physicians (Conlon, 2010). Glucose and hemoglobin A1C of APRN patients were lowered to a greater extent than patients of physicians. The patients of physicians lost more weight than the APRN patients but it was due to their patients having weight loss due to hyperglycemia. Blood pressures were equivalent in both groups. Education was offered, initiated, and charted on more in the APRN group. The second study of diabetics compared a consistent APRN provider to volunteer physicians in a not-for-profit clinic (Condosta, 2012). Glucose, hemoglobin A1C, HDL, LDL, referrals to ophthalmology and podiatry, and monofilament testing were the measures analyzed. It was a five year study starting in 2004. Retrospective chart audits were completed looking at the aforementioned measures. All the measures were equivalent with the exception of the monofilament testing and referrals to podiatry and ophthalmology, which were better managed by APRNs than physicians.

Other studies included patient's subjective perceptions only. One such study compared patient satisfaction in an occupational health care setting (Guzik, Menzel, Fitzpatrick, \& McNulty, 2009). A convenience sample of 129 patients was selected and a satisfaction survey was completed by each of the patients. There was no difference in satisfaction noted between provider types. Another study looked at patient's perception of their individual health and their satisfaction with care (Pinkerton \& Bush, 2000). A sample of 160 patients, ranging in age from 18 to 89 , was surveyed on these two concepts. The provider type had no bearing on patients' 
perspectives of their health or satisfaction. In short, all of the research reviewed was homogenous showing that APRNs have at least equivalent outcomes to physicians in varied settings and measurements.

The literature review on the topic of political involvement of nurses involved searching CINAHL, Pubmed, and Medline databases. The terms used in all database searches were “nurses" "political involvement" and "policy. The search of PubMed resulted in 50 documents. The search in CINAHL had the limitations of being published in or after 1998 in English and of a United States subset; 57 documents resulted. The Medline search resulted in 40 hits.

The documents were then reviewed for content and all that were not systematic reviews or research were excluded. Nine studies resulted. In addition to these nine studies, the referenced works from these studies was reviewed in an attempt to gather additional research on the topic of nurses' political involvement. From this analysis, seven additional studies were found. Finally the articles were reviewed and studies that were not of a quantitative nature were excluded. This resulted in six descriptive studies.

The studies included in this review primarily evaluated the success of specific methods used to increase political involvement of nurses. Two research articles looked at before and after involvement subsequent to collegiate policy classes; one at the Bachelor's level and the other at the Master's level (Byrd, et al., 2012; Rains \& Carroll, 2000). Both groups experienced an improvement in political confidence and astuteness after completing a policy class. The third study looked at how nurses engaged politically before and after a Legislative Day (Primomo \& Bjorling, 2013). Political astuteness scores again increased statistically significantly after participating in the program. Another study compared female nurses' political involvement compared to females in other professions, specifically engineering and teaching (Hanley, 1987). 
Nurses were noted to have significantly less membership in their professional organization(s), and were less likely to vote compared to the other female professionals. The professions all campaigned, protested and participated in communal activity at similar rates. The fifth study looked specifically at nurse practitioners with an attempt to discern the extent of political involvement of this specific group. This study documented that voting was the most common political activity at (87\%) followed by donating to campaigns (57\%), contacting political officials (56\%) and providing policy related information (50\%) (Oden, Price, Altenede, Boardley, \& Ubokudom, 2000). Of note, the population of this study was identified through their membership in their professional organization. Those who belong to professional organizations are likely more involved and engaged in policy than those without said membership. The last study looked at specific factors that led to nurses joining their respective professional organizations and found that the nurses' involvement in organized political activity was most influenced by resources, particularly available time, and feelings of personal political efficacy (Cramer, 2002).

The findings of all studies were consistent in purporting that nurses are ambivalent or apathetic to political participations. Several reasons for the failure include a lack of confidence in political ability, ignorance as to the significance of politics and policy, the impression that nurses cannot make a difference, the shift in nursing care from communities to individuals, and the perception of nursing as a non-political profession (Byrd, et al., 2012; Bimber, 2000; Cramer, 2002; Hanley, 1987; Oden, Price, Altenede, Boardley, \& Ubokudom, 2000; Primomo \& Bjorling, 2013; Rains \& Carroll, 2000). Methods to overcome such ambivalence were suggested in a number of the articles which included the need for nursing educators to increase curriculum in nursing policy development, nursing interest groups translating political involvement as a 
patient care activity, having nursing educators and those in practice work more in tandem, and the creation of mechanisms to bring issues forward in one voice (Byrd, et al., 2012; Cramer, 2002; Primomo \& Bjorling, 2013; Rains \& Carroll, 2000). The proposed project is intended to overcome several of the noted reasons for nurses' apathy and encourage nurses to be involved in the political process in regard to the singular issue of full practice authority for NPs.

\section{Congruence of Organizations Strategic Plan to Project}

The project was not associated with a specific organization however it supported the strategic plan of several groups. The West Virginia Nurses Association supports legislation that ends the collaborative agreement requirement in the state of WV in order to increase access to care for patients, recognize APRNs as capable and competent to practice at the full scope of their education and training, and to prevent restraint of trade (West Virginia Nurses Association, 2013). Likewise, the American Nurses Association supports full practice authority for APRNs and works with all states to remove legislation that limits such practice (American Nurses Association, 2013). Working off the recommendations found IOM's "Future of Nursing", the Roberts Wood Johnson Foundation and AARP have joined to form the Campaign for Action. This initiative is establishing state constituent groups throughout the country to support the institution of the eight recommendations outlined by the IOM, the first of which is for APRNs to be able to practice at the full scope of the education and training (Campaign for Action, 2013). The project was aligned with the goals of these organizations.

The WVNA, the ANA and the Campaign for Action all need grassroots political support from the nursing profession to achieve the aforementioned policy goals. The project was a method to engage APRNs to support legislation needed in the state of WV that to contribute to achieving the common goal of APRN full practice authority. 


\section{Measurable Project Objectives}

The primary objective measured for this project was the extent to which advanced practice nurses communicate quality information to the West Virginia legislature during the legislative session related to a nursing issue. Specifically an attempt to contact all of the advanced practice nurses of WV was made via traditional mail requesting they review the created website. The website included a survey page which asked the participant whether they personally contacted, in any form, a legislator in the last session (2013) regarding full practice authority nursing legislation (Senate Bill 379). It also asked if they would be contacting their legislator during the current session in support of Senate Bill 212 and whether they would share the website either via a link or verbalization.

Engaging with a legislator regarding the issue of nursing full practice authority was measured by analysis of the completed website surveys. Actual emails sent from the website were also analyzed. Other general observations made include the total number of visits to the website, number of visitors to the website, the total number of page hits on the website, the

number of hits per page, and the breakdown of contacts between APRNs and APRN students. A tertiary observation made was the end result of the full practice authority legislation introduced in the 2014 session. An activities chart is appended (Appendix A).

\section{Project Design}

\section{Evidence Based Intervention}

The project centered on the creation of a website to provide objective, factual data and evidence regarding APRNs full practice authority. The website was referenced in an outreach campaign to WV APRNs with the request that they go on to share the website with their elected 
WV legislators. The measurable objective was comparing political involvement before and after being introduced to the website.

A similar project, although of a different topic, was completed in Calgary, an urban center of Canada, in 2001. It involved the creation of a website and email campaign advocating for a smoking ban that was being proposed by the city council. An internet survey was conducted on 2,200 individuals invited to the website. Twenty-six percent of those contacted responded $(n=605)$. The respondents reported $35.8 \%$ of them had contacted their elected official(s) regarding any issue prior to the internet campaign. After participating with the internet campaign, respondents' contact with their elected official(s) rose to $66.1 \%$ with $50.8 \%$ saying they anticipated being active in future policy development (Greirson, Van Dijk, Dozious, \& Mascher, 2006).

The aforementioned project did have a sizeable marketing budget which included advertising on city buses, billboards, trains and newspapers. The ads invited people to the website. Three thousand citizens were registered in the first three months of the site's existence. Information on the site included harms of second hand smoke, suggested messages to forward to city officials, and a registration section that allowed registrants to be informed of the campaign's progress including "calls to action". For example, each time the issue was to be discussed at a council meeting an email was sent to all registrants informing them of the meeting date, location and time. City officials reported an overwhelming response that was more pronounced than any public feedback they had received on any previous issues (Greirson, Van Dijk, Dozious, \& Mascher, 2006).

The past twenty years has included a momentous evolution of the internet. The impact of this vehicle on different elements of society has, and continues to be, the subject of research and 
debate. In regards to the effect of the internet on politics and public policy, there has been a noted positive association between heavy internet use and volunteer, political and civic involvement (Sullivan, et al., 2002; Wellman, Quan Haase, Whilte, \& Hampton, 2001). A reason behind this association is the organizational element that can be utilized with the internet that can promote civic action (Calhoun, 1998). There has also been speculation that the biggest impact the internet may have is engaging citizens that, while typically politically inactive, are interested as well as anticipation that internet campaigns may come to replace institutionalized advocacy (Bimber, 2000; Delli Campini, 2000).

To capitalize on the aforementioned findings associated with internet use, the site designed for this project included an easy method for visitors to email their elected legislators. The site included suggested language to include in the email or the email could be completely personalized. A link to the website was included in all outgoing emails from the site. In addition both a Facebook account and Twitter account were created to make communicating updates more efficient and less time consuming for the registrants of the site. Participants self registered for these updates.

\section{Timeline}

West Virginia has a part time legislature. The timing of the proposed project was inextricably tied to the $2014 \mathrm{WV}$ legislative session as the goal of the project was to measure APRN communication with state legislators regarding the issue of full practice authority. In 2014 the session was scheduled from January $8^{\text {th }}$ through March $8^{\text {th }}$.

The new website was built from August through December 31, 2013 and was up and running on January $8^{\text {th }}$. The contact list of APRNs in WV was received from the WV Board of Nursing (WVBON) in September. It included 1,843 APRNs. Of the 1,843 APRNs, 458 were 
from out of state and thus excluded from the population. Fourteen letters were returned with bad addresses. This resulted in 1,371 letters sent and assumed to be received by APRNs in WV. Based upon work from previous sessions and discussions that were ongoing prior to the session, a full practice authority bill was anticipated to be introduced in the Senate soon after the session began and indeed it was on January 8th. Legislation was not introduced in the House until January $27^{\text {th }}$. Therefore while it was anticipated that the letters would have been sent out sooner, the project letter was sent to the APRNs on January 30, 2014 after bills had been introduced in both houses of the legislature. The letter directed APRNs to the website created for this project. The website included specific information, including bill numbers for the proposed legislation regarding APRN practice. Data from the survey were collected through February 28, 2014. While the end of the session was not until March 8, 2014, the bills both died in committee prior to the end of the session and thus the data collection stopped before the legislative session ended but after the bills ran out of time to get out of committee.

\section{Resources}

The largest single anticipated expense of the proposed project was the cost associated with developing the website. Multiple bids were requested from various website vendors. The average price of development was $\$ 3,800$ and the lowest bid was $\$ 2,000$. This cost included building the site in its entirety with the vendor being given the information to include on the site. In addition the vendor would arrange email capability from the site to the legislature. The vendor would also design a survey. Specifically the questions asked include: if the participant is an APRN or APRN student, if they contacted their legislator during the previous session to support the APRN full practice bill (SB 379), and if they did if they provided evidence to support their position. The survey went on to ask if they intended to contact their legislators during the current 
session to support the full practice authority bills introduced and if so, if they intended to share a link to the website developed for this project and if the website influenced them to become involved in the political process. While it was initially anticipated to have the APRNs drill down to the type of provider, including nurse practitioner, certified nurse midwife, nurse anesthetists, or clinical nurse specialists, however it was decided that the most important aspect of data collection for this project evaluation was the communication with elected officials and not requesting such differentiation would allow for simplicity in completion of the survey included in the website. Thankfully, the development of the site was donated in-kind by an APRN colleague's spouse who is proficient in web design and computer programming.

Other resources required include postage, paper and envelopes to mail out invitations to the website to APRNs, a printer and toner to print said invitations, and a computer to utilize for the project. The cost of the supplies and postage needed for the paper invitations totaled $\$ 956$. Labor resources include those hours required to gather, format and transmit to the web designer the information to be included on the site. The time estimated and hourly rate for the information gathering and formatting was calculated at a competitive nurse practitioner rate. It took 16 hours per week over a 15 week period. At a rate of $\$ 50$ per hour, this time, contributed in kind, equaled $\$ 9,600$. In addition, an administrative assistant was utilized to assist with transmitting the gathered data to the web designer. This, at 60 hours at a rate of $\$ 10$ per hour, resulted in a cost of $\$ 600$. The final cost was for the monthly fee for web hosting of the site which was $\$ 6$ per month, totaling $\$ 60$ to date. In addition to the nurse practitioner hours donated in-kind, the computer and printer were also donated. These assets value is approximately $\$ 1200$. In total the value of the inkind resources donated was $\$ 12,800$. The funds needed to complete the project were just over $\$ 1,700$. The WVU School of Nursing provided $\$ 500$ in capstone project assistance funding. The 
remainder was self-funded. The vast majority of the costs were one-time expenses and recurring costs would be minimal should the project be sustained. A full budget is appended to this proposal (Appendix D).

\section{Project Results}

\section{Data Analysis}

One hundred surveys $(n=100)$ were completed by visitors to the project website through the end of February, 2014. This included 17 APRN students and 81 APRNs; two surveys were completed by neither of these categories and thus excluded from analysis. The eighty-one APRN respondents were from a pool of 1,371 potential participants contacted via letter with an invitation to the website indicating a participation rate of $6 \%$ for APRNs. Seventeen APRN students completed the survey. The number of APRN students in the state currently is unknown but 17 is surely a minimal participation rate. As previously mentioned, despite the fact that the legislative session lasted until March 9th, the bills addressing full practice had died in their respective committees and the WVNA had sent an email out reporting such before the end of session. Thus data collection stopped as the information emailed to many of the APRNs in WV served as a disincentive for participation in the project.

Descriptive statistics were used to analyze the collected data. There were two primary objectives of the project. The first was an analysis of whether, by the introduction of a website tool that could be used to communicate with legislators, an increase would be noted in said communication between the 2013 and 2014 West Virginia legislative sessions, both of which had similar full practice authority bills for APRNs. The second objective was to analyze any relationship present between the introduction of the website tool and the provision of 
documentation that supports the full practice goals of APRNs. Chi-square tests were utilized to analyze the data for each of the objectives. It was found that the introduction of the website did positively influence communication to legislators asking they support the full practice authority bill of 2014. In addition, the website positively influenced the communication of quality documentation that supports APRN full practice to legislators in 2014.

Interestingly, the raw data appeared to convey that APRN students neither had experience nor as much desire to contact their legislators regarding scope of practice legislation compared to established APRNs. However when data analysis was done using the Chi-square test, there was no significant association noted between status as an APRN versus a student and contacting a legislator after introduction to the website as the p value was 0.7452 .

In addition to the aforementioned statistical analysis, other data were collected from the website. Utilizing Google Analytics, the following data is summarized:

Number of total visits to the website

Number of actual visitors to the website

Page hits

Pages viewed per visit

New vs returning visitors percentage

Country of visitor

$1 \quad$ Aruba
237

187

2,037

5.12

$77.5 \%$ new/22.5\% returning

236 United States

There are seven pages on the website. They include the home page, updates, research, state statutes, survey, supporters, and contact us (Appendix E). Of the page hits of 2,037 the following were the counts on each page:

Home page 
Updates

Research

State statutes

Survey

Supporters

Contact us
42

155

101

743

189

135

In looking at data comparing APRNs to APRN students, of the respondents, 17 were APRN students, two were neither APRNs nor APRN students and 81 were APRNs. A total of 30 (30.6\%) respondents had contacted their legislators last year to support SB 379. Of those 30 who had contacted their legislator in 2013, only one was an APRN student (1\%). Thus 29 were established APRNs (29.6\%). After exposure to the website, 58 of the respondents (59.2\%) anticipated contacting their legislators in support of the full practice authority bills for APRNs in this session. Of those 58, six (10.3\%) were APRN students with the remaining 52 (89.6\%) being established APRNs. Fifty-four (56.1\%) of the respondents were influenced by the website to contact their legislators. Of these, seven (12.9\%) were APRN students and the remaining 47 (87\%) were APRNs. Finally, 67 (68.4\%) of the respondents intended to refer their legislators to the designed website in order to convey supportive documentation for APRN full practice authority. Of these 67, nine were APRN students (13.4\%) and the remaining $58(86.5 \%)$ were APRNs.

As part of this project, Facebook and Twitter accounts were created. The number of visitors to the Facebook page, which was created 2/08/2014, was 316 as of February 28, 2014. Of those 316, there were likes, comments and sharing of the Facebook page with 228 
participants of Facebook. In regard to Twitter, there were only 6 applicants who subscribed to this method of communication.

\section{Project Objectives}

The objective of this project was to increase the extent advanced practice nurses communicate quality information to the West Virginia legislature during session related to a nursing issue. This actually breaks down into two research questions: 1.) Does the introduction of a website tool that provides quality information on APRN's full practice and a method to contact legislators increase the amount of legislative contacts by APRNs and APRN students? 2.) Does the introduction of a website tool that provides quality information on APRN's full practice and a method to contact legislators increase the amount of supporting documentation provided to legislators in support of the issue of interest?

The Chi-square analysis for the first objective compared legislative contacts of APRNs and APRN students after accessing the developed website and the legislative contacts made by the same population during the previous year when no website tool was available. A total of 30 respondents had contacted their legislators last year to support SB 379. After exposure to the website, 58 of the respondents anticipated contacting their legislators in support of the full practice authority bills for APRNs in this session. Results indicated a strong statistical association between legislative contact and the introduction of the website tool with a p value of $<0.0001$. To assure continuity correction, McNemar's test was also run on the collected data. The two-tailed $\mathrm{p}$ value of McNemar's test was also $<0.0001$ which again indicates a statistically significant change in the proportion of participants contacting their legislators following introduction to the developed website tool. 
The project objective analyzed by the Chi-square testing compared if APRNs and APRN students provided legislators with supportive documentation for the full practice bill during the current year when the website was introduced via provision of a link to the website versus the previous year when such website was not available. Sixty-seven of the respondents $(67 \%)$ intended to refer their legislators to the designed website. The Chi-square test on this data found a strong statistical relationship between providing supportive documentation to legislators and introduction to the developed website with a $\mathrm{p}$ value of $<.0001$. Again the McNemar's test was run to assure continuity correction and showed a statistically significant change in the proportion of participants providing supportive documentation to the legislators after reviewing the developed website with a two-tailed p value of 0.0433 .

Interestingly, the raw data appeared to convey that APRN students neither had experience nor as much desire to contact their legislators regarding scope of practice legislation compared to established APRNs. However when data analysis was done using the Chi-square test, there was no significant association noted between status as an APRN versus a student and contacting a legislator after introduction to the website as the p value was 0.7452 .

Another anomaly noted within the data analysis was the relatively few contacts made directly through the website from APRNs/APRN students to their respective legislators. Despite 58 APRN/APRN students who intended to contact their legislators, only three APRNs utilized the website to contact their ten respective legislators.

Ultimately the full practice authority bills introduced in 2014 to the West Virginia Legislature died in both chambers of the legislature while still in their respective Health \& Human Services Committees. In the House of Delegates, a subcommittee of the Health \& Humans Services Committee was formed to study the issue during interim sessions, with 
Delegate Denise Campbell (D-Randolph), a registered nurse, selected as chair of the subcommittee. The Senate did not address the bill in any manner. Of note, the Senator who serves as the chair of the Senate Health \& Human Services Committee is a primary care physician who has been the primary opponent to all APRN full practice authority bills introduced over the years.

\section{Unintended Consequences}

Several negative unintended acts occurred during the project. The first was that the open letter that was supposed to be published in the January edition of the WV Nurse, which is published quarterly and received by all registered nurses in WV, was excluded from that publication. The WVNA's executive director had emailed the publisher a list of the content to be included in the January issue and the open letter was included in that email. However for some unknown reason, the publisher neglected to include it. This severely limited the exposure of the website to APRN students. While personal letters were sent out to WV APRNs inviting their participation, there was no easily accessible database available to request the addresses of all WV APRN students. Additionally, the publication of the open letter would likely have positively impacted the participation of APRNs in the survey as well as visits to the site.

A second unintended occurrence was the early end of data collection. The surveys were intended to be completed and compiled until March 9, 2014. Despite the fact that bills have a certain date for which they need to be out of committee and introduced to the other chamber, the website did not disclose such information and this is largely an unknown rule. However, an email was sent out from the WVNA the last week of February that informed members of the death of the bills in their respective committees. Because this likely served as a disincentive to 
participate in the website and survey, the data collection ended February $28^{\text {th }}$ rather than March $9^{\text {th }}$

In regard to the actual bills introduced during the 2014 session, a significant event occurred that negatively impacted the consideration of the bill. The WVNA had completed an application that had been filed with the WV Legislative Auditors, in the Performance Evaluation and Research Division (PERD). This is required to be done when a profession is seeking a change in scope of practice. That application was filed with PERD in the spring of 2014. West Virginia Code requires the PERD to have a response to the application by the third week of December so it can have time to be reviewed by the joint Government Organization Committee during interim session. The joint Government Organization Committee is tasked with submitting an opinion on the findings of the PERD application and this opinion carries significant weight in the likelihood of bill passage during the following regular session. Despite the statute that requires PERD to have their report complete in December, the WVNA, as the applicant, was notified the third week of December that the PERD had been granted an extension to complete their report addressing the APRN scope of practice expansion until the first week of February, 2014. At the time of extension the PERD was questioned as to what impact such an extension was going to have on the ability to have legislative changes for APRNs during the 2014 session. The PERD responded that, despite the extension, there would still be time to introduce legislation and have it considered during the 2014 session. In reality, opponents to the bill used the fact that the report had not gone through the interim session to refuse to put the bill on the committee's agenda. Their opinion was the bill could not be legislatively considered until the 2015 session at which time the report would have been reviewed during the 2014 interim sessions starting in May. This was a major disappointment to all those involved in getting 
APRNs in WV to be able to practice to their full capabilities. For opponents to the bill, it allowed yet another method to delay consideration of the issue.

\section{Sustainability of Project}

Advanced practice registered nurses have, for years, been arguing their ability to provide independent, quality care to patients without the need to have physician involvement dictated statutorily. Attention was piqued in 2010 when the Institute of Medicine publically declared a need for APRNs to practice independently in order to provide quality care to Americans. But it has been the Affordable Care Act, which is set to increase the number of insured patients nationwide that has created the furry of concern regarding the lack of primary care providers available for these newly insured citizens. Full practice authority for APRNs has been forwarded by a number of organizations as a way to provide some relief to the provider shortage.

There are currently thirty-one states, including WV, that do not have full practice authority for APRNs. The proposed project was intended to be helpful in furthering the effort for independent practice for APRNs in WV. It could easily be transitioned to work for the states that seek full practice authority. The costs associated with developing the website were, for the most part, one-time expenses thus funds to continue the site would only be associated with monthly web hosting (\$6/month). Additional costs could include updating the information on the site as applicable. It is likely this could be contributed in-kind by an APRN who is engaged in furthering the cause of full practice authority. This project could easily be assumed by a national nursing organization such as the American Nurses Association (ANA) or the American Association of Nurse Practitioners (AANP). These organizations maintain a web presence 
currently and much of the information on the proposed website is included on their sites however, it is included amongst a large amount of other information. With a link to the created website from the ANA or AANP's website, individual representatives from constituent states could easily access the site. Because all of the information on the site is related to full practice authority, there is no required sorting or perusing of data in order to find applicable information. The legislative links set up to email state representatives providing them a link to the site could be updated for each state participating through the site. This could be done by the national organization that adopts the sponsorship of the proposed site or by individual states that desire to use the site as a lobbying tool. It will only be when every state allows full practice authority for APRNs that the proposed site will be obsolete. Until that point, it could easily be supported and sustained, with modest expenses, by interested parties involved in furthering nursing practice.

\section{Discussion and Recommendations}

The objective of the project was to increase the involvement of APRNs and APRN students in the political process. Nurses have exhibited low levels of participation in the political

process over recent years. Research suggests reasons for such, including a limit on time, a lack of confidence in communicating their needs, and a lack of noticing and understanding the impact of policy on the needs of nurses and patients (Bimber, 2000; Byrd, et al., 2012; Cramer, 2002; Hanley, 1987; Oden, Price, Altenede, Boardley, \& Ubokudom, 2000; Primomo \& Bjorling, 2013; Rains \& Carroll, 2000). The development of a website tool for APRNs and ARPN students to utilize that included research on the competence of APRNs as well as a link to the statutes of full practice authority states and a method to contact their legislators was intended to provide a method of communication for APRNs/APRN students and arm them with ample evidence to communicate with their legislators. This tool was meant to aide in overcoming the 
limitations found in the research of the lack political participation of nurses in issues that involve them by saving them time and providing them with quality information to specifically communicate.

The website had a positive impact on the participation level of respondents in supporting scope of practice legislation in play during the 2014 legislative session. Fifty-eight respondents contacted or intended to contact their legislators regarding 2014 full practice legislation for APRNs compared to 30 who had contacted their legislators on the same issue the previous year. The website also had a positive effect on conveying specific information supporting full practice to legislators with $67 \%$ of respondents saying they would refer their respective legislators to the website, which includes such information supporting the full practice bill, compared to $47 \%$ who offered supportive documentation during the previous session on the same issue.

It is noted that $100 \%$ of all respondents, whether students or APRNs, who intended to contact their legislators after being introduced to the website were planning to reference the developed website to their legislators. This is consistent with the research that shows one of the reasons nurses do not participate in the legislative process is due to lack of comfort relating to what information to convey to elected representatives.

There are several hypotheses as to why so few participants chose to use the project website to contact their legislators. The first explanation could be that those that completed the survey were unable, at the time of survey completion, to correspond to their legislators and completed the correspondence at a later date. The second explanation could be that the website did not offer the ease of communication that the respondent's personal email could. The final 
consideration is that respondents could have articulated their intent to communicate in their survey but never completed the action with their legislators.

The data collected from the social media pages showed a sizeable participation through Facebook but only six people became followers on the associated Twitter account. While specific data on the age of respondents was not collected, one reason for such numbers could be related to the participants in lobbying for full practice authority are of a generation this is not as comfortable with using Twitter compared to their younger counterparts.

\section{Future Recommendations}

The project's objectives of increasing the amount of contacts APRNs and APRN students had with their legislators and increasing the amount of evidence provided to legislators in support of a nursing issue were both met. The objectives of this project are in congruence with the organizational strategic plans of the WVNA, the ANA and the WV Campaign for Action. Specifically the WVNA's Health Policy \& Legislative Statement includes, as its first goal, support of full practice authority for APRNs in the state (West Virginia Nurses Association, 2013). Likewise the ANA provides as one of its major initiatives protecting the scope of practice of APRNs and removing limitations that prevent APRNs from practicing to their full scope of training and education (American Nurses Association, 2013). The WV Campaign for Action, as well as the national Campaign for Action group, is tasked with getting the IOM's Future of Nursing goals instituted in WV and around the country, the first of which is removing barriers that prevent APRNs from practicing to their full extent (Campaign for Action, 2013).

Considering the similarities between the project's goals and the organizational goals of the WVNA, the ANA, and the WV Campaign for Action, along with the fact that the project's goals were achieved, it stands to reason that these organizations could continue, and perhaps, 
expand the project. The cost associated with the continuation of the current website in West Virginia is likely to be minimal. The monthly cost to maintain the site is $\$ 6$. The cost to continue to utilize the current webmaster is unknown at this time as the services have been donated inkind up to this point. However, because of the fact that the data would require only minimal updates, it is anticipated to be relatively inexpensive. There is also the possibility that a current member of WVNA who is technologically savvy could contribute webmaster services in-kind. The provision of data to the webmaster to update the website could, in all likelihood, be contributed in-kind by a member of the WVNA.

Other states that do not have laws allowing full practice for APRNs could benefit from utilizing the developed website. This would require updates on the site as the home page, the legislative contact links, and the contact information page would need to be edited per state. However the state statue and research pages would be exactly the same. The cost projection for WV would apply to each state desiring to adopt the website with the exception of slightly higher expense for a paid webmaster to update the aforementioned pages of the website. Again it is presumed a member of the states' nursing association could serve in-kind to provide the webmaster the necessary information to update the website. It is also possible a webmaster's services could be contributed in-kind. The ANA could be asked to provide contact information to the presidents of each state's nursing association that does not have full practice authority in order to assess the interest of these states.

Another consideration for expansion is utilizing the general format developed for the website to address other nursing issues found in bills of the state legislatures or Congress. Of course the information relating to other nursing issue under legislative consideration would have to be gathered and organized in a fashion similar to the current website. This would take 
additional time and cost unless volunteers could be found to provide such services. Again each state organization would make the decision on using such a tool at the state level while the ANA would likely be the deciding body relating to the formulation of such a site for an issue being considered by the United States Congress.

\section{Professional Attainments}

This DNP project provided a number of personal benefits related to leadership. As part of the project I served closely with the Executive Board of the WVNA to work on the legislative issue of interest. Because of this involvement I was recently awarded the WVNA's Politically Active Nurse Award for 2014. Also through contacts I have made while working on this project with nursing educators involved with the WVNA, I have been asked to guest lecture on policy issues for the WVU's master's level Policy class for the past two years.

By working on this project, I have also developed a strong relationship with Senator Bob Beach (D-Monongalia) who is my representative in the WV Senate. This relationship has led to Senator Beach becoming a champion for the issue of APRN full practice authority in WV. He has been the primary sponsor for the full practice bills in WV for the past two years, was awarded by the WVNA last year for his advocacy and is being awarded this year by the American Association of Nurse Practitioners for excellence in nursing advocacy in the state of WV.

I have considerably honed my skills in social media management, website development and analytics used to measure such activities. This knowledge is anticipated to have long term applicability, as it is likely to remain an important method of communication through the foreseeable future. 
Throughout the DNP program I have evolved from a person with an interest in full practice authority for APRNs to an expert in the area, including the research that has been completed on the issue and the statutes of states with full practice. I have been contacted by APRNs, APRN students, the WVNA, WV legislators and WV media sources with questions on other states' APRN laws and research findings on the quality of care of APRNs. Not only have I gained the knowledge necessary to be an expert in this area of advanced practice nursing, but the DNP program has, perhaps more importantly, equipped me with the confidence to acknowledge that I am a leader in this area. The work and analysis completed during this project has the potential to positively impact APRNs and patients. Using a tool similar to the website developed for this project, can help to assure APRNs are successful in attaining full practice authority and patients will have access to quality care for the future. 


\section{References}

American Academy of Nurse Practitioners. (2012). Nurse Practitioner Facts. Retrieved from American Academy of Nurse Practitioners Website: https://www.aanp.org/images/documents/research/2010-2011np\%20facts2012.pdf

American Academy of Nurse Practitioners. (2013). State Practice Environment. Retrieved from American Academy of Nurse Pracititioners Web site: https://www.aanp.org/legislationregulation/state-practice-environment

American Association of Retired People. (2011, September). Removing barriers to advanced practice registered nurse care. Retrieved from AARP Web site: http://assets.aarp.org/rgcenter/ppi/health-care/insight55.pdf

American Nurses Association. (2013). About ANA. Retrieved October 26, 2013, from American Nurses Association: http://nursingworld.org/FunctionalMenuCategories/AboutANA

American Nurses Association. (2013). Advanced Practice Nursing: Scope of Practice. Retrieved September 29, 2013, from American Nurses Association Website: http://nursingworld.org/EspeciallyForYou/AdvancedPracticeNurses/Scope-of-Practice-2

Anderer, T. (2008). Health promotion and disease management in primary care: a comparison of nurse practitioner and physician practice patterns on four selected HEDIS outcomes.

Bakerjian, D. (2008). Care of nursing home residents by advanced practice nurses: a review of the literature. Research in Gerantological Nurses, 177-185.

Bevis, L., Berg-Copas, G., Thomas, B., Vasquez, D., Wetta-Hall, R., Brake, D., . . Harrison, P. (2008). Outcomes of tube thoracostomies performed by advanced practice providers vs trauma surgeons. American Journal of Critical Care, 357-363.

Bimber, B. (2000). The study of information technology \& civic engagement. Political Communication, 409-428.

Byrd, M., Costello, J., Gremel, K., Schwager, J., Blanchette, M., \& Malloy, T. (2012). Political astuteness of baccalaureate nursing students following an active learning experience in health policy. Public Health Nursing, 29(5), 433-443.

Calhoun, C. (1998). Community without propinquity revisited: communications technology and the tranformation of the urban public sphere. Sociological Inquiry, 373-397.

Campaign for Action. (2013). State Action Coalitions. Retrieved from Campaign for Action Website: http://campaignforaction.org/states 
Campbell, R. (2008). Change managment theory in health care. The Health Care Manager, 27(1), 23-29.

Coddington, J., Sands, L., Edwards, N., Kirkpatrick, J., \& Chen, S. (2011). Quality of heath care provided at a pediatric nurse managed clinic. Journal of the American Academy of Nurse Practitioners, 674-688.

Condosta, D. (2012). Nurse Practitioner and MD Providers in Diabetes Care. Journal for Nurse Practitioners, 792-796.

Conlon, P. (2010). Diabetes outcomes in primary care: evaluation of the diabetes nurse practitioner compared to the physician. Primary Health Care, 20(5), 26-31.

Cramer, M. (2002). Factors influencing organized political participation in nursing. Power, Politics \& Policymakers, 97-107.

Delli Campini, M. (2000). Gen.com: youth, civic engagement, and the new inforamation environment. Political Communication, 341-349.

Dulisse, B., \& Cromwell, J. (2010). No harm found when nurse anesthetists work without supervision by physicians. Health Affairs, 29(8), 1469-1475.

Fairman, J., Rowe, J., Hassmiller, S., \& Shalala, D. (2011, January 20). Brodening the scope of nursing Practice. New England Journal of Medicine, 293-196.

Federal Trade Commission. (2012, September 11). Prepared Statement of the federal trade commission staff before subcommitee A of joint committee on health of the State of WV legislature. Retrieved from Federal Trade Commission: http://www.ftc.gov/os/2012/09/120907wvatestimony.pdf

Goad, S., \& Hough, L. (1993). Lewin's field theory with emphasis on change. In Theory directed nursing practice (pp. 179-98). New York: Springer Publishing.

Golden, A. (2012, August 17). Personal Communication to Conneticut Public Health Committee. American Academy of Nurse Practitioners.

Greirson, T., Van Dijk, M., Dozious, E., \& Mascher, J. (2006). Using the Internet to Build Community Capacity . Health Promotion Practice, 14-22.

Guzik, A., Menzel, N., Fitzpatrick, J., \& McNulty, R. (2009). Patient satisfaction with nurse practitioners and physician services in the occupational health setting. AAOHN Journal, 191-197.

Hanley, B. (1987). Political participation: how do nurses compare with other professional women? Nursing Economics, 4, 179-185. 
Institute of Medicine. (2010). The future of nursing: leading change, advancing health. Washington DC: National Academies Press.

Jackson, G. L. (2010). Employment of mid-level providers in primary care and control of diabetes. 5(1), 25-31.

Jackson, G., Lee, S., Edelman, D., Weinberger, M., \& Yano, E. (2010). Employment of mid level providers in primary care and control of diabetes. Primary Care Diabetes, 5(1), 2531.

Kotter, J. (2012). Leading Change. Boston: Harvard Business Review Press.

Kouzes, J., \& Posner, B. (2012). The leadership challenge. San Francisco: Jossey-Bass.

Laurant, M., Reeves, D., Hermens, R., Braspenning, J., Grohl, R., \& Sibbald, B. (2007). Substitution of doctors by nurses in primary care. Cochrane database of systematic reviews, 4.

Lenz, E., Mundinger, M., Kane, R., \& Hopkins, S. W.-Y. (2004). Primary care outcomes in patients treated by nurse practitioners or physicians: two year follow up. Medical Care Research and Review, 332-351.

Litaker, D., Mion, L., Planavsky, L., Kippes, C., Mehta, M., \& Frolkis, J. (2003). Physician nurse practitioner teams in chronic disease management: the impact on costs, clinical effectiveness and patients perception of care. Journal of Interprofessional Care, 17(3), 223-233.

Mundinger, M., Kane, R., Lenz, E., Totten, A., Tsai, W., Cleary, P., . . Shelanski, M. (2000). Primary care outcomes in patients treated by nurse practitions or physicians: a randomized trial. JAMA, 59-68.

National Governor's Association. (2012, December). The role of nurse practitioners in meeting increasing demand for primary care. Retrieved from National Govenor's Association: http://www.nga.org/files/live/sites/NGA/files/pdf/1212NursePractitionersPaper.pdf

Newhouse, R. H. (2011). Advanced practice nurse outcomes 1990-2008. Retrieved from Nursing Economics:

http://midwife.org/ACNM/files/ccLibraryFiles/Filename/000000001305/Advance\%20Pra ctice\%20Nurse\%20Outcomes\%20article.pdf

Oden, L., Price, J., Altenede, R., Boardley, D., \& Ubokudom, S. (2000). Public policy involvement by nurse practitioners. Journal of Community Health, 139-155.

Pinkerton, J., \& Bush, H. (2000). Nurse practitioners and physicians: patients perceived health and status with care. Journal of the American Academy of Nurse Practitioners, 211-217. 
Primomo, J., \& Bjorling, E. (2013). Changes in political astuteness following nurse legislative day. Policy, Politics, Nursing Practice, 1-12.

Rains, J., \& Carroll, K. (2000, January). The effect of health policy education on self-perceived policitcal competence of graduate nursing students. Journal of Nursing Education, 39(1), $37-40$.

Sullivan, J., Borgida, E., Jackson, M., Riedel, E., Oxendine, A., \& Gangl, A. (2002). Social capital and community electronic networks. American Behavioral Scientist, 868-886.

US Department of Health \& Human Resources. (2013). Quick Access Maps. Retrieved September 29, 2013, from Health Resources and Services Administration Data Warehouse: http://datawarehouse.hrsa.gov/default.aspx

Wellman, B., Quan Haase, A., Whilte, J., \& Hampton, K. (2001). Does the internet increase, decrease, or supplement social capital? Americal Behavioral Scientist, 436-455.

West Virginia Department of Health \& Human Resources. (2012, August 21). Frequent Requested Statistics. Retrieved from Health Statistics Center: http://www.wvdhhr.org/bph/hsc/statserv/Stat_triv.asp\#HealthConditions

West Virginia Nurses Association. (2013). 2013 Health Policy \& Legislative Position Statement. Charleston, West Virginia.

Wright, W., Romboli, J., DiTulio, M., Wogen, J., \& Belletti, D. (2011). Hypertension treatment and control wihtin an independent NP setting. American Journal of Managed Care, 5865. 
Appendix A - Activities Chart

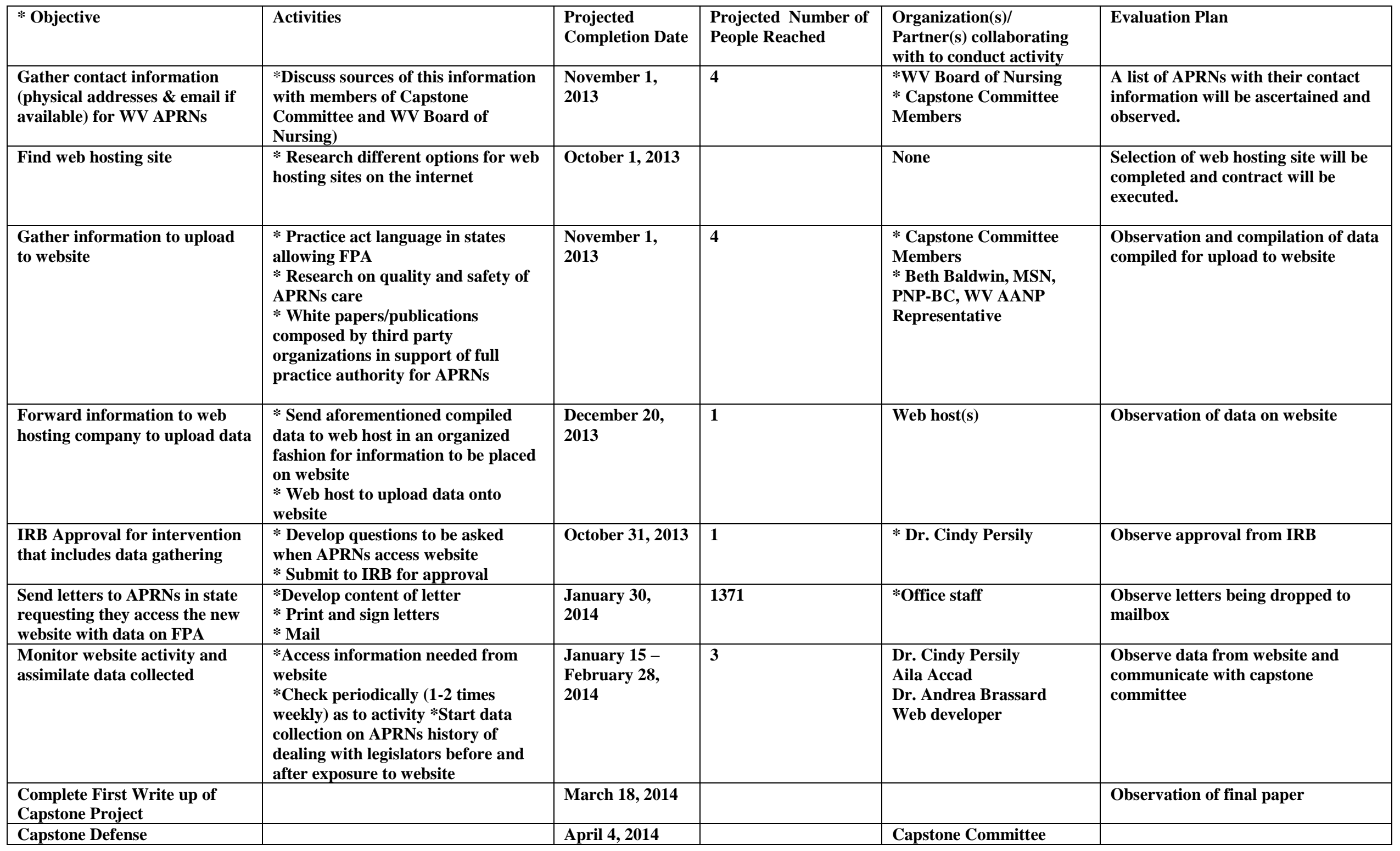


Appendix B - Timeline

\begin{tabular}{|c|c|c|c|c|c|c|c|c|c|c|c|c|c|c|c|c|c|}
\hline \multirow[t]{2}{*}{ Task } & \multicolumn{12}{|c|}{2013} & \multicolumn{5}{|c|}{2014} \\
\hline & Jan & Feb & Mar & Apr & May & June & July & Aug & Sept & Oct & Nov & Dec & Jan & Feb & Mar & Apr & May \\
\hline $\begin{array}{l}\text { Gather contact } \\
\text { information on WV } \\
\text { NPs }\end{array}$ & & & & & & & & & & & & & & & & & \\
\hline $\begin{array}{l}\text { Create website with } \\
\text { full practice authority } \\
\text { information (state } \\
\text { comparisons - } \\
\text { statutes, research } \\
\text { citations/summary, } \\
\text { documents supporting } \\
\text { FPA for NPs by } \\
\text { organizations) }\end{array}$ & & & & & & & & & & & & & & & & & \\
\hline $\begin{array}{l}\text { Contact NPs in state } \\
\text { and reference to web } \\
\text { page, collect political } \\
\text { involvement data, } \\
\text { encourage contact to } \\
\text { their respective } \\
\text { legislators \& track FPA } \\
\text { legislation }\end{array}$ & & & & & & & & & & & & & & & & & \\
\hline $\begin{array}{l}\text { Collect data logged on } \\
\text { website }\end{array}$ & & & & & & & & & & & & & & & & & \\
\hline $\begin{array}{l}\text { Compile comparative } \\
\text { analysis of data } \\
\text { (pre/post website) }\end{array}$ & & & & & & & & & & & & & & & & & \\
\hline $\begin{array}{l}\text { Share findings with } \\
\text { national organizations } \\
\text { (ANA/AANP) to see if } \\
\text { interest in using site } \\
\text { for other states } \\
\text { legislative efforts }\end{array}$ & & & & & & & & & & & & & & & & & \\
\hline
\end{tabular}


Appendix C -

Letter to WV APRNs and APRN students

Dear WV APRN and APRN students:

I would like to invite you to participate in research I am conducting on political behavior of advanced practice registered nurses (APRNs). I have developed a website relating to safety, efficacy and support of APRNs full practice authority. This website is part of the research project that I am conducting for my Capstone Project for the Doctorate of Nursing Practice degree I am pursuing at West Virginia University. WV IRB approval is on file. The site address is www.WVAPRNs.com and it will be available as of 1/15/2014.

The benefit of visiting the site includes the potential for knowledge expansion from the educational information provided on the site including statutory language of states with full APRN practice, research summaries and citations in which the effectiveness of APRN care was studied, and links to documents from non-nursing organizations that support APRN full practice. Another benefit is having a time-saving manner for you to participate in the political process and support of the full practice authority bill in WV as the website contains a method for you to share a link to the site with your elected legislators and write a note asking their support for the legislation

Finally, there is a Survey on the site that I would like all APRNs and APRN students residing in West Virginia that visit the site to take. It will take less than 5 minutes to complete. The survey results are anonymous so you cannot be linked to the answers you provide. There is no way to trace which visitors to the site choose to take the survey. The survey questions do not involve personal health information or anything that would put you in legal or financial risk. For those APRNs who are WVU employees or WVU students, the decision not to participate in the research by not completing the survey will have no impact on employment or academic status at WVU.

This project was motivated by research that shows the nursing profession as generally disengaged in the political process. My goal is to analyze survey data regarding involvement in the political process when an important APRN issue is being affected by proposed legislation. If you have any questions, concerns or comments related to this project, please email me at dichiacchio@yahoo.com. I appreciate your participation and will share my findings with you via the website in April, 2014.

Thank you,

Toni DiChiacchio, MSN, CEN, FNP-BC 
Appendix D - Project Budget

\begin{tabular}{|l|c|c|}
\hline \multicolumn{1}{|c|}{ Budget Categories } & Requested Funds & In-Kind Contributions \\
\hline ADMINSTRATIVE COSTS & $\$ 760.00$ & $\$ 11,600.00$ \\
\hline
\end{tabular}

Administrative justification: Salary of Nurse Practitioner for 15 hours per week during website development (16x12=192 hours $\mathrm{x}$ \$50/hour=\$9600) [In-kind]; \$2,000 - designer for website development assistance based upon lowest bid submitted

(Designquote.com)[In-kind from personal contact donating time to develop website] ; 60 hours during website development for assistant to upload data to site $(\$ 10 / \mathrm{hr} \times 60=\$ 600)$; web hosting fees $(\$ 20.00$ per month $\mathrm{x} 8$ months $=\$ 160)$

\begin{tabular}{|c|c|c|}
\hline MARKETING & $\$ 0$ & $\$ 0$ \\
\hline \multicolumn{3}{|l|}{ Marketing justification: } \\
\hline $\begin{array}{l}\text { EDUCATIONAL MATERIALS/ } \\
\text { INCENTIVES }\end{array}$ & $\$ 0$ & $\$ 0$ \\
\hline HOSPITALITY (food, room rentals, etc.) & $\$ 0$ & $\$ 0$ \\
\hline \multicolumn{3}{|l|}{ Hospitality justification: } \\
\hline \multicolumn{3}{|c|}{$\begin{array}{l}\text { Project supplies justification: Two reams of paper for letters to APRNs asking their visit to website }(\$ 18 / \text { ream x } 3=\$ 54 @ \text { Staples.com) } \\
\text { Toner for printer }(\$ 178.99 @ \text { Staples.com); Letter envelopes }(\$ 11 / \text { box of } 500 @ \text { Staples.com; } \$ 30.16) \text {; Postage to send out } 1371 \text { letters } \\
(\$ .46 \text { x } 1371=\$ 630.66) \text {; Printer (Brother } 9970 \mathrm{CDW} @ \text { Staples.com - \$699.99) [In-kind] Laptop computer (Samsung RV511 @ } \\
\text { Staples.com - \$500.00) [In-kind] }\end{array}$} \\
\hline PATIENT CARE & $\$ 0$ & $\$ 0$ \\
\hline \multicolumn{3}{|l|}{ Patient Care justification: } \\
\hline GROSS TOTALS & $\$ 1,653.81$ & $\$ 12,799.99$ \\
\hline \multicolumn{3}{|l|}{ WVU Capstone Assistance Funds Received } \\
\hline NET TOTALS & $\$ 1,153.81$ & $\$ 12,799.99$ \\
\hline
\end{tabular}


Appendix E - Website pages

Homepage

Full Practice Authority for WV APRNs | improving healthcare access \& choice

Page 1 of 3

\section{FULL PRACTICE AUTHORITY FOR WV APRNS}

improving healthcare access \& choice

\section{Welcome to WV APRNs}
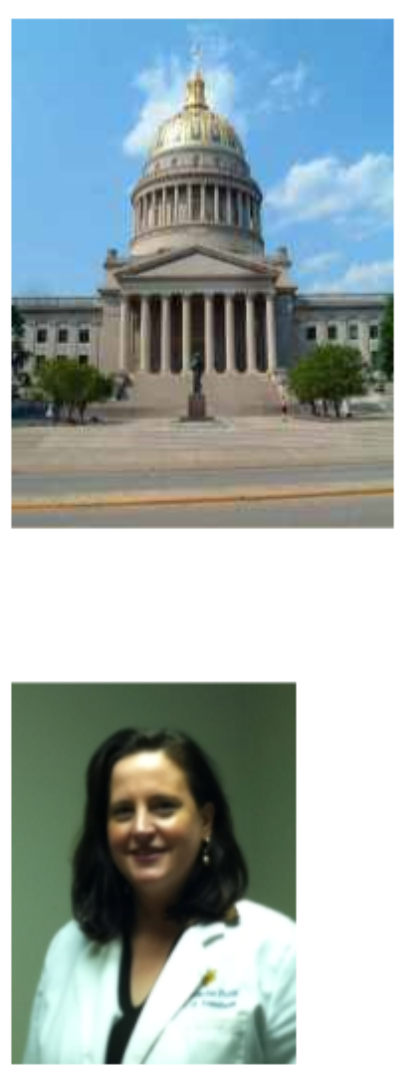

03-05-2014 - Thank you to all the nurses who participated in my study. The bills we had in the legislature this session both died in their respective committees. Despite that loss, Senator Kessler (Senate President) has vowed to have meetings the week after the session ends to discuss the issue and attempt to put together a bill all parties are satisfied with to be introduced in the legislature 
Full Practice Authority for WV APRNs | improving healthcare access \& choice

Page 2 of 3

next session. The PERD report will also be discussed during interims in the joint Government

Organization committee.

I encourage you to keep posted on this issue, consider a trip to Charleston during the discussion of the PERD report in interim session and to continue to discuss the issue with your legislators.

In addition, this is an election year in which many current legislators are up for re-election. This is a prime time to discuss the issue of full practice authority for APRNs with the candidates running for a seat in WV's legislature. And of course, vote for those candidates that support our issue.

Stay involved in the political process,

Toni DiChiacchio, MSN, CEN, FNP-BC

My name is Toni DiChiacchio and this web site has been created as part of my Doctorate of Nursing Practice (DNP) Capstone Project. I am studying the political involvement of West Virginia APRNs. If you are a West Virginia APRN or West Virginia APRN Student, please consider participating in my study by completing the questionnaire under the "Survey" section of this website.

While this site is being utilized as part of my study of West Virginia APRNs political participation, the content on the site will be educational for anyone interested in full practice authority for APRNs. The site has the following content:

- Links to the statue and rules of states that already have full practice which educates visitors on legal language currently used.

- Links to reports and publications of non-nursing groups who support full practice for APRNs.

- A summary of some of the research done over the past 40 years in which APRN quality and safety were studied

Please Like and Visit Our WVAPRNs Facebook Page!

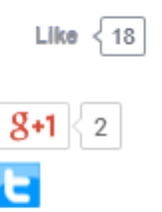

http://www.wvaprns.com/

$3 / 15 / 2014$ 
Appendix E - Website pages, con't

Updates

Updates | Full Practice Authority for WV APRNs

http://www.wvaprns.com/updates/

\section{FULL PRACTICE AUTHORITY FOR WV APRNS}

\section{Updates}

\section{Latest Updates}

1/27/2014:2/6/14: Border state of Kentucky passes SB 7, the first passed bill of their session, with overwhelming support. It expands the scope of practice for Kentucky APRNs:

http://www.Irc.ky.gov/record/14RS/SB7.htm

1/27/2014: 2/2/14: WVNA Press Release on APRN practice:

http://myemail.constantcontact.com/PRESS-RELEASE-APRN.html?soid=1105271776926\& aid $=$ LAL5jO-jVFM

1/27/2014: 1/30/14: Performance Evaluation \& Review Division (PERD) report on APRNs released

http://www.legis.state.wv.us/Joint/PERD/reports.cfm

1/27/2014: HB 4342 Assigned to Health \& Human Resources Committee

$2 / 7 / 2014$ - Nurses push legislators to remove restrictions on practice in WV 
Charleston, WV - More than 2,100 competent Advance Practice Registered Nurses(APRNs) in West Virginia are trying to fill the provider gap by providing unrestricted cost-effective, comprehensive, quality patient-centered care. They are pushing legislators to pass HB 4342 and SB 212 on removing restrictions to APRNs practicing to their full abilities in WV.

Nurses do not need medical oversight. APRNs are expert clinicians with advanced education. Most have masters and many have doctorate degrees and extensive clinical experience. APRNs partner with their patients, guiding them to make educated health care decisions and healthy lifestyle choices. The research proves time and again that APRNs get great outcomes for their patients. Eighteen states and the District of Columbia have already lifted these outdated restrictions.

Nurses do not want to be doctors. Medicine and Nursing are separate and independent professions. Every profession has a unique focus. If you think of healthcare as a continuum,

Illness $<\frac{\text { Health Care Continuum }}{\text { Medicine Nursing }}>$ Health

Medicine specializes toward the left on the continuum. Nursing specializes toward the right. There is an overlap (+++) in the middle where the use of certain healthcare strategies overlap. Doctors and nurses collaborate and refer patients to each other as appropriate.

"No one discipline "owns" any particular health care skill or service" Six health care regulatory organizations-including the Federation of State Medical Boards and the National Council of State Boards of Nursing-acknowledged this principle and recommended legislators use this frame when determining licensure requirements. Medication is used by both Nursing and Medicine. Professionals from both disciplines complete courses in pharmacology, medication selection and monitoring. APRNs are required to demonstrate competency in prescribing skills for certification.

Nurses provide a health focus for WV. Health reform is about strengthening the right side of the continuum with earlier access to care focusing on less costly health education, health promotion, wellness and care coordination instead of waiting until illness is obvious or advanced. That is why the Institute of Medicine (IOM) published a major report on Future of Nursing (2010). This report focuses on improving patient care and addressing challenges in the existing health care system by strengthening Nursing's role for better health outcomes. Their number one recommendation is to remove barriers to all nurses, especially advanced practice nurses (APRNs), functioning to the full scope of what they are educated and licensed to do, so more people have earlier access to a full range of health options.

Collaboration is a standard of professional nursing practice. Half of all APRNs have been granted prescription writing privileges. This has been the case for over 20 years in WV. These 
current bills do not change what nurses are licensed to do. These bills simply retire outdated and unnecessary legislative limitations that hamper patients from getting direct access to all the services of APRNs. The requirement for a signed collaborative agreement between the nurse and a physician means that if that physician retires or moves, the APRN must stop providing those treatments until he/she can find another physician to sign the agreement. APRN Sam Cotton, quipped, "I have been seeing patients independently before my physician collaborator wos born."

The most important issue is that this proposed legislative change will enhance consumers' access to competent healthcare services.

\section{1/8/2014: SB 212 "Expanding prescriptive authority of advanced nurse} practitioners and certified nurse-midwives" was introduced in the

\section{Senate}

\section{1/8/2014: SB212 Assigned to Health \& Human Resources Committee}

\section{Considerations for site visitors:}

- Thank the sponsors of SB 212

- Lead sponsor - Senator Bob Beach (Monongalia Co.) at bob.beach@wvsenate.gov or (304)357-7919

- Co-sponsor - Senator Rocky Fitzsimmons (Ohio Co.) at rocky@fitzsimmonsfirm.com or (304)357-7918

- Co-sponsor - Senator Bob Williams (Taylor Co.) at bob.williams@wvsenate.gov or (304)357-7995

- Contact the members of the Health \& Human Resources Committee to ask the bill be placed on their agenda (to the chair) and supported (all members)

- Chair - Senator Ron Stollings (Boone Co.) at ron.stollings@frontier.com or (304) 357-7939

- Vice Chair - Senator William Laird (Fayette Co.) at william.laird@wvsenate.gov or (304) 357-7849

- Members

- Senator Art Kirkendoll (Logan Co.) at art.kirkendoll@wvsenate.gov or (304) 
357-7857

- Senator Ronald Miller (Greenbrier Co.) at ronald.miller@wvsenate.gov or (304) 357-7959

- Senator Corey Palumbo (Kanawha Co.) at corey.palumbo@wvsenate.gov or (304) 357-7880

- Senator Robert H. Plymale (Wayne Co.) at robert.plymale@wvsenate.gov or (304) 357-7937

- Senator Roman Prezioso (Marion Co.) at roman.prezioso@wwsenate.gov or (304) 357-7961

- Senator Gregory A. Tucker (Nicholas Co.) at greg.tucker@wvsenate.gov or (304) 357-7906

- Senator Jack Yost (Brooke Co.) at jack.yost@wvsenate.gov or (304) 357-7984

- Senator Donna J. Boley (Pleasants Co.) at donnaboley@suddenlink.net or (304) 357-7905

- Senator Bill Cole (Mercer Co.) at bill.cole@wvsenate.gov or (304) 357-7843

- Senator Mike Hall (Putnam Co.) at mike.hall@wvsenate.gov or (304) 357-7901

- Senator Chris Walters (Putnam Co.) at chris.walters@wvsenate.gov or (304) 357-7866

Remember to share the link to this site (WVAPRNs.com) with any contact you make with your legislators regarding full practice authority for APRNs.

Like 0

$8+10$

E

- 2013 EmbeddedHorizon Com 
Appendix E - Website pages, con't

Research

Research | Full Practice Authority for WV APRNs

Page 1 of 16

\title{
FULL PRACTICE AUTHORITY FOR WV APRNS
}

\author{
improving healthcare access \& choice
}

\section{Research}

\section{Research on APRN care}

No other health care providers have been studied as much as APRNs. For over 40 years the quality and safety of their care has been researched with not a single study, of over one hundred completed, showing any safety or quality of care problems. Much of the research is listed with citations and summaries below. Share this information with lawmakers when supporting full practice for WN APRNs in order to show the excellent care APRNs provide and to demonstrate how the public will be at no risk if full practice is allowed in WV.

\section{Systematic Reviews/Meta-Analysis}

KuetheMC, Vaessen-Verberne AAPH, Elbers RG, Van AalderenWMC. Nurse versus physician-led care for the management of asthma. Cochrane Database of Systematic Reviews 2013, Issue 2.

Research Question: How does asthma care provided by NPs compare to that of physicians?

Results: Included 5 RCTs with 588 patients. Providers were equivalent in cost, number and severity of asthma exacerbations and patient quality of life.

\footnotetext{
Newhouse, R., Stanik-Hutt, J., White, K., Johantgen, M., Bass, E., Zangaro, G., Wilson, R., Fountain, L, Steinwachs, D., Heindel, L \& Weiner, J. (2011). Advanced practice nurse outcomes 1990-2008: a systematic review. Nursing Economics 29(5): 230-251.

Research Question: Compared to other providers (physicians or teams with APRNs) are APRN outcomes of care similar?
} 
Results: 37 studies were included for analysis and the findings indicate the nurse practitioners and certified nurse midwives provide care that results in comparable, and in some ways better, patient outcomes than physicians alone.

Hatem M, Sandall J, Devane D, Soltani H, Gates S. Midwife-led versus other models of care for childbearing women. Cochrane Database of Systematic Reviews 2008, Issue 4.

Research Question: How to mid-wives compare to physicians in the care of childbearing women?

Results: 11 trials, involving 12,276 women. Midwife-led care was associated with several benefits for mothers and babies, and had no identified adverse effects. The main benefits were a reduction in the use of regional analgesia, with fewer episiotomies or instrumental births. There was no difference in caesarean birth rates. Women with midwives were less likely to lose their baby before 24 weeks' gestation, although there were no differences in the risk of losing the baby after 24 weeks, or overall. Women with midwives were more likely to have a shorter length of hospital stay.

Laurant, M., Reeves, D., Hermens, R., Braspenning, J., Grol, R., \& Sibbald, B. (2006). Substitution of doctors by nurses in primary care. Cochrane Database of Systematic Reviews. 2006, Issue 1.

Research Question: How do patient outcomes compare between physicians and nurses in primary care?

Results: Meta-analysis including 25 articles relating to 16 studies comparing outcomes of primary care nurses and physicians. The quality of care provided by nurses was as high as that of the physicians. Overall, health outcomes and outcomes such as resource utilization and cost were equivalent for nurses and physicians. The satisfaction level was higher for nurses.

Horrocks, S., Anderson, E., Salisbury, C. (2002). Systematic review of whether nurse practitioners working in primary care can provide equivalent care to doctors. British Medical Journal, 324, 819823.

Research Question: How do nurse practitioners compare to physicians in primary care? 
Results: A systematic review of 11 randomized clinical trials and 23 observational studies identified data on outcomes of patient satisfaction, health status, cost, and/or process of care. Patient satisfaction was highest for patients seen by NPs. The health status data and quality of care indicators were too heterogeneous to allow for meta-analysis, although qualitative comparisons of the results reported showed comparable outcomes between NPs and physicians. NPs offered more advice/information, had more complete documentation, and had better communication skills than physicians. NPs spent longer time with their patients and performed a greater number of investigations than did physicians. No differences were detected in health status, prescriptions, return visits, or referrals. Equivalency in appropriateness of studies and interpretations of $x$-rays was also noted.

Brown, S.A. \& Grimes, D.E. (1995). A meta-analysis of nurse practitioners and nurse midwives in primary care. Nursing Research, 44(6), 332-9.

Research Question: How do nurse practitioners compare with physicians regarding patient outcomes?

Results: A meta-analysis of 38 studies comparing a total of 33 patient outcomes of NPs with those of physicians demonstrated that NP outcomes were equivalent to or better than those of physicians. NP patients had higher levels of compliance with recommendations. Patient satisfaction and resolution of pathological conditions were greatest for NPs. The NP and physician outcomes were equivalent on all other outcomes.

\section{Literature Reviews}

Bauer, J. (2010). Nurse practitioners as an underutilized resource for health reform: evidence based demonstrations of cost effectiveness. Journal of American Academy of Nurse Practitioners, 228231.

Research Question: What impact do NPs have on quality outcomes of patient care and cost of healthcare services?

http://www.wvaprns.com/research/ 
Research $\mid$ Full Practice Authority for WV APRNs

Page 4 of 16

Results: Economic analysis and literature review show nurse practitioners provide care of equal or better quality at lower cost than comparable services provided by other qualified health professionals, including physicians.

Hogan, Seifert, Moore \& Simonson (2010). Cost effectiveness analysis of anesthesia providers. Nursing Economic\$2010; 28(3): 159-169.

Research Question: How is the quality of patient care and cost affected by CRNAs providing anesthesia without physician supervision?

Results: Literature review and analysis of 52,636 claims in 2008 from Ingenix National Database and data from 52,233 discharges from 2006 National Survey of Ambulatory Surgery found the quality of care provided by CRNA is equivalent to physicians at a lessor cost.

Bakerjian, D. (2008). Care of Nursing Home Residents by Advanced Practice Nurses: A Review of the Literature. Research in Gerontological Nursing, 1(3), 177-185.

Research Question: What does the literature show regarding APRNs practicing in nursing homes in regard to clinical effectiveness, costs, and resource utilization?

Results: Literature review of 38 studies on care of nursing home patients by APRNs consistently shows APRN care in nursing homes improves residents care. The review shows significant support for APNs in a variety of roles in nursing homes including NPs providing primary and acute care and CNSs providing education and consultation services.

Office of Technology Assessment. (1986). Nurse practitioners, physician assistants, and certified nurse midwives: A policy analysis. Washington D.C.: US Government Printing Office

Research Question: How do APRNs compare to physicians and physician assistants in caring for patients?

http://www.wvaprns.com/research/ 
Results: The Office of Technology Assessment reviewed studies comparing nurse and physician practice, concluding that, "NPs appear to have better communication, counseling, and interviewing skills than physicians have." Malpractice premiums and rates supported patient satisfaction with NP care

Prescott, P.A. \& Driscoll, L (1980). Evaluating nurse practitioner performance. Nurse Practitioner, 1 (1), 28-32.

Research Question: How to nurse practitioners compare to physicians in providing healthcare?

Results: Literature review of 26 studies comparing NP and physician care. NPs scored higher in : amount/depth of discussion regarding child health care, preventative health, and wellness; amount of advice, therapeutic listening, and support offered to patients; completeness of history and followup on history findings; completeness of physical examination and interviewing skills; and patient knowledge of the management plan given to them by the provider. Other findings were equivalent among the two professions.

Congressional Budget Office. (1979). Physician extenders: Their current and future role in medical care delivery. Washington, D.C.: US Government Printing Office.

Research Question: Are nurse practitioners safe and competent to deliver healthcare?

Results: Congressional Budget Office reviewed findings of the numerous studies of NP performance in a variety of settings and concluded that NPs performed as well as physicians with respect to patient outcomes, proper diagnosis, management of specified medical conditions, and frequency of patient satisfaction.

\section{Randomized Control Studies}

Ettner, S.L, Kotlerman, J., Abdelmonem, A., Vazirani, S., Hays, R.D., Shapiro, M., et al. (2006). 
Research $\mid$ Full Practice Authority for WV APRNs

Page 6 of 16

An alternative approach to reducing the costs of patient care? A controlled trial of the multidisciplinary doctor-nurse practitioner (MDNP) model. Medicol Decision Making, 26, 9-17.

Research Question: What is the impact on healthcare costs of including nurse practitioners in patient care?

Results: Significant cost savings were demonstrated when 1207 patients in an academic medical center were randomized to either standard treatment or to a physician-NP model.

Lenz ER, Mundinger MO, Hopkins SC, Lin SX, and Smolowitz JL (2002). Diabetes care processes and outcomes in patients treated by nurse practitioners or physicians. Diabetes Education, 28 (4):590-8.

Research Question: How do specific care processes and outcomes compare between NPs and physicians caring for adult primary care Type II diabetics?

Results: After reviewing the charts of 145 subjects randomized to the care of either an NP or a physician, it was found that NPs document more than physicians in regard to providing patient education, height, urinalysis and $\mathrm{A} 1 \mathrm{C}$ results. No differences were found in the documentation of weight, blood pressure, social history, medications, ophthalmology referrals, depression, cardiovascular and foot exams, blood glucose and creatinine test results. Patient outcomes between the groups were equivalent.

Lenz ER, Mundinger MO, Kane RL, Hopkins SC, Lin SX. (2004). Primary care outcomes in patients treated by nurse practitioners or physicians: two-year follow-up. Med Care Res Rev. 61(3): 332-51.

Research Questions: How does adult diabetic care by either an NP or a physician compare after two years of care?

Results: After reviewing the charts of 406 adult type II diabetics receiving care from either an NP or a physician, no differences were found between the groups in health status, disease specific physiologic measures, satisfaction or use of specialist, emergency room or inpatient services. NPs achieved equivalent outcomes with less primary care visits, on average, than physicians.

http://www.wvaprns.com/research/ 
Litaker D, Mion L, Planavsky L, Kippes C, Mehta N, Frolkis J. (2003). Physician - nurse practitioner teams in chronic disease management: the impact on costs, clinical effectiveness, and patients' perception of care. Journal of Interprofessional Care. 17(3):223-37.

Research Question: What is the impact on costs, outcomes and patient satisfaction when cared for by an NP-physician team versus a physician alone?

Results: Analysis of the charts of 157 patients randomized to an NP-physician team or a physician alone found that, while one year personnel costs were higher amongst the team providers, A1C and $\mathrm{HDL}$ values were significantly improved, as was patient satisfaction, amongst patients who received care that included NPs.

Cooper, M.A., Lindsay, G.M., Kinn, S., Swann, IJ. (2002). Evaluating emergency nurse practitioner services: A randomized controlled trial. Journal of Advanced Nursing, 40(6), 771-730.

Research Question: How to nurses compare to physicians as emergency care providers?

Results: A study of 199 patients randomly assigned to emergency NP-led care or physician-led care in the U.K. demonstrated the highest level of satisfaction and clinical documentation for NP care. The outcomes of recovery time, symptom level, missed work, unplanned follow-up, and missed injuries were comparable between the two groups.

Mundinger, M., Kane, R., Lenz, E., Totten, A., Tsai, W., Cleary, P., Friedewald, E., Siu, A., \& Shelanski, M. (2000). Primary care outcomes in patients treated by a nurse practitioner or physician: a randomized trial. JAMA. 283 (1): 59-68.

Research Questions: When NPs are given exactly the same level of authority and autonomy, how to patient outcomes and satisfaction compare to physicians.

Results: Analysis of 1316 patients who had no prior primary care provider and who were randomly assigned to a physician or nurse practitioner after an ER/Urgent Care visit in an urban academic 
Research $\mid$ Full Practice Authority for WV APRNs

Page 8 of 16

medical center showed that patient satisfaction, utilization and outcomes related to diabetes,

hypertension and asthma were comparable between physicians and NPs.

Sacket, D.L, Spitzer, W. O., Gent, M., \& Roberts, M. (1974). The Burlington randomized trial of the nurse practitioner: Health outcomes of patients. Annals of Internal Medicine, 80(2), 137-142.

Research Question: How do nurse practitioners compare to physicians regarding patient outcomes?

Results: Random assignment of a sample of 1598 families. Two-thirds received primary care from a family physician and one-third received care from a NP. Outcomes measured included mortality, physical function, emotional function, and social function. Results showed comparable outcomes for patients in both groups.

\section{Descriptive Observational Studies}

Condosta, D. (2012). Comparison between nurse practitioners and MD providers in diabetic care. The Journal for Nurse Practitioners, 8(10), 792-796.

Research Question: How does the care of diabetic patients in a free clinic compare between a consistent NP provider and volunteer physicians?

Results: 262 charts of NPs and 52 charts of physicians of diabetic patients in a free clinic were reviewed for care provided between 2004-2009. NP visits and the volunteer MD visits did not differ statistically for A1C, HDL, or LDL goal attainment. Ophthalmology and podiatry referrals and microfilament testing were somewhat more frequent in 2008 and 2009 for the NP provider versus the volunteer MDs.

Fletcher, C., Copeiand, L, Lowery, J., Reevers, P. (2011)Nurse Practitioners as Primary Care Providers within the VA. MILTARYMEDICINE, 176, 791-96.

http://www.wvaprns.com/research/ 
Research Question: What are the perceptions of physicians and NPs about NP care and how do hypertension and diabetes outcomes compare between care provided by an NP versus a physician?

Results: Physicians' perceptions of what NPs do on their own were underestimated. Clinical findings for patients with hypertension and/or diabetes were comparable between patients cared for by an NP or physician.

Conlon, P. (2010). Diabetes outcomes in primary care: evaluation of the diabetes nurse practitioner compared to the physician. Primary Health Care, 20(5), 26-31.

Research Questions: How does patient education and outcomes of diabetic patients compare when cared is provided by an NP versus a physician.

Results: Analysis of 27 patient charts found that patients cared for by an NP had more diabetic education documented and had a lower A1C than when cared for by a physician.

Dulisse \& Cromwell (2010). No Harm Found when Nurse Anesthetists Work without Supervision. Health Affairs 29 (8): 1469-1475

Research Question: Are surgical patients' complications or death rates increased when a CRNA works without physician supervision?

Results: Analysis of Medicare data for 1999-2005 found no evidence that CRNAs that practice without supervision result in increased surgical inpatient deaths or complications.

Jackson, GL, Lee, SY, Edelman, D., Weinberger, M. and Yano, EM. (2010) Employment of mid-level providers in primary care and control of diabetes. Primary Care Diabetes, 5(1), 25-31. Epub 2010 Oct 25.

Research Question: What is the impact on outcomes of diabetic patients in primary care when their care includes that of a NP or a physician's assistant?

http://www.wvaprns.com/research/

$3 / 15 / 2014$ 
Research $\mid$ Full Practice Authority for WV APRNs

Page 10 of 16

Result: A1C values of 88,682 VA patients from 198 clinics were reviewed. Patients that had an NP involved in their care were found to have significantly lower A1C values than when cared for by a physician alone. In the patients whose care included physician's assistants there was no noted difference in A1C except when PAs where employed at moderate levels. In these cases, A1C levels were actually higher than when patients were cared for by physicians alone.

Chen, C., McNeese-Smith, D., Cowan, D., Upenieks, V., \& Afifi, A. (2009). Evaluation of a nurse practitioner led care management model in reducing inpatient drug utilization and cost. Nursing Economics, 160-168

Research Question: What is the economic impact of a multidisciplinary team co-lead by a NP and Hospitalist medical director on the use of pharmaceutical resources among general medicine inpatients?

Results: After analysis of pharmaceutical claims data of 1,200 subjects who participated in the Multidisciplinary, Physician, and Nurse Practitioner Study from 2000 to 2004 it was found that the teams led by NPs had significant reduction in drug cost and drug utilization.

Anderer, T. (2008). Health promotion and disease management in primary care: a comparison of nurse practitioner and physician practice patterns on four selected HEDIS outcomes. Dissertation.

Research Question: Are there differences between care provided by NPs compared to physicians in regard to breast and cervical cancer screening and control of diabetes and hypertension?

Results: No statistically significant differences were found between the provider types for ordering breast or cancer screening, nor for hypertensive control. Diabetic control was comparable between the two groups but physicians actually ordered more lab test for A1C than the NPs.

Chenowith, D., Martin, N., Pankowski, J., \& Raymond, L (2005). A benefit cost analysis of a worksite nurse practitioner program. Journal of Occupational \& Environmental Medicine, 1110-6

http://www.wvaprns.com/research/ 
Research $\mid$ Full Practice Authority for WV APRNs

Page 12 of 16

Guzik, A., Menzel, N., Fitzpatrick, J., \& McNulty, R. (2009). Patient satisfaction with nurse practitioner and physician services in the occupational health setting. AAOHN Journal, 57(5), 191 -

197.

Research Question: Is patient satisfaction different when clinical services are provided by nurse practitioners versus physicians in the occupational health setting.

Results: 129 patients visiting occupational care clinics for new work related injury comprised the convenience sample for this study. No difference was found in patient satisfaction between patients seen by NP vs physicians.

Sears, J., Wickizer, T., Franklin G., Cheadle A., \& Berkowitz B. (2007). Nurse practitioners as attending providers for injured workers. Evaluating the effect of role expansion on disability and costs. Medical Care (MED CARE), 2007 Dec; 45 (12): 1154-61.

Research Question: What are the differences in medical costs and disability outcomes for injured workers cared for by NPs as compared to those cared for by physicians?

Results: Analysis of the medical records, claims and billings of 29,949 injured workers in Washington state over one year (2004-2005) showed NPs more likely than physicians to be located in rural areas and counties with high unemployment; distributions of injury type and severity/complexity indicators similar across provider types; likelihood of any time loss was lower for NP claims, but duration of lost work time and medical costs did not significantly differ by provider type.

Coddington, J., Sands, L, Edwards, N., Kirkpatrick, J. \& Chen, S. (2011). Quality of health care provided at a pediatric nurse-managed clinic. Journal of the American Academy of Nurse Practitioners, 23 (2011) 674-680.

Research Question: What is the quality of care received at a pediatric nurse-managed clinic (NMCs) that provides health care for the underserved pediatric population?

http://www.wvaprns.com/research/ 
Research Questions: What is the economic impact on an organization that starts an on-site nurse practitioner initiative to provide healthcare to employees and their families compared to using physicians and other healthcare providers in the community?

Results: Comparing the costs of the NP clinic to previous year's healthcare costs for 4284 employees and their dependents found the first 6 months of a new NP initiative yielded substantial reductions in healthcare costs. The full value of the NP initiative may understate the aggregate value of the program because it may also reduce on-site injury and illness patterns and improve productivity, end points that were not assessed in the initial study.

\section{Wright, W., Romboli, J., DiTulio, M., Wogen, J. \& Belletti, D. Hypertension Treatment and Control Within an Independent Nurse Practitioner Setting (2011). Am J Manag Care. 2011;17(1):58-65)}

Research Question: Are there differences in blood pressure control of patients taken care of by a nurse practitioner compared to patients cared for by physicians.

Results: Hypertensive patients in 3 independent NP clinics ( $\mathrm{n=684)}$ were compared to 21 physician clinics ( $\mathrm{n}=3232$ ). Among the NP cohort, $70.5 \%$ had controlled BP compared with $63.2 \%$ among physician cohort; mean number of BP meds used was lower among NP-treated patients (1.6 vs 1.8, $\mathrm{P}=0.1$ ) Paez, K. \& Allen, J. (2006). Cost-effectiveness of nurse practitioner management of hypercholesterolemia following coronary revascularization. Journal of the American Academy of Nurse Practitioners, 18, (2006) 436-444.

Research Question: Is there cost-effectiveness in having case management by a nurse practitioner (NP) to lower blood lipids in patients with coronary heart disease (CHD) from a managed care perspective

Results: 228 patients with high cholesterol and CHD post revascularization were randomized to usual care or usual care plus lipid management by an NP clinic x 1 year. After 1 year of intervention, the average LDL-C and TC levels were significantly lower in the NP group than usual care group and the NP clinic was cost effective. 
Results: 500 charts of pediatric patients (birth-21 yrs old) at pediatric nurse managed clinic in Indiana were reviewed. The results showed the nurse managed pediatric clinic met or exceeded national HEDIS benchmark standards of care and targets set by OMPP for quality of care.

Ohman-Strickland, P.A., Orzano, AJ., Hudson, S.V., Solberg, LI., DiCiccio-Bloom, B., O'Malley, D., et al. (2008). Quality of diabetes care in family medicine practices: Influence of nurse-practitioners and physician's assistants. Annals of Family Medicine, 6(1), 14-22.

Research Question: How do NPs and physician's assistants impact diabetic patient care?

Results: Cross-sectional study of 46 practices, measuring adherence to ADA guidelines. Practices with NPs were more likely to perform better on quality measures including appropriate measurement of glycosylated hemoglobin, lips, and microalbumin levels and were more likely to be at target for lipid levels.

Bevis, L, Berg-Copas, G., Thomas, B., Vasquez, D., Wetta-Hall, R., Brake, D., Lucas, E. Toumeh, K., \& Harrison, P. (2008). Outcomes of tube thoracostomies performed by advanced practice providers vs. trauma surgeons.

Research Question: How does the quality of tube thoracostomies performed by advanced practice providers compare to that performed by trauma surgeons?

Results: 51 charts of patients receiving tube thoracostomies in the hospital were reviewed. Differences between practitioner type in insertion complications, complications requiring additional interventions, hospital length of stay, and morbidity were not significant. The only significant difference was a complication related to placement of the tube when the tube extended caudad, toward the feet, from the insertion site.

Laurant, M. et al., (2007). An overview of patients' preference for, and satisfaction with, care provided by general practitioners and nurse practitioners. Journal of Clinical Nursing, 17, 2690 $-2698$.

http://www.wvaprns.com/research/ 
Research $\mid$ Full Practice Authority for WV APRNs

Page 14 of 16

Research Question: Do patients' prefer NPs or physicians for care? Is patient satisfaction with NPs the same as with physicians? What factors influence patients' preferences and satisfaction?

Results: 235 patients who received care from both nurse and doctor completed a self-administered questionnaire. Patients preferred the doctor for medical aspects of care, whereas for educational and routine aspects of care half of the patients preferred NPs or had no preference; patients were generally very satisfied with both nurse and doctor; patients were significantly more satisfied with the nurse for those aspects of care related to the support provided to patients and families and to the time made available to patients; variations in preference and satisfaction were mostly attributable to variation in individual patient characteristics, not doctor, nurse or practice characteristics.

Roblin, D.W., Becker, R., Adams, E.K., Howard, D. H., \& Roberts, M.H. (2004). Patient satisfaction with primary care: Does type of practitioner matter? Medical Care, 42(6), 606-623.

Research Question: How does patient satisfaction compare between NPs, PAs and physicians?

Results: A retrospective observational study of 41,209 patient satisfaction surveys randomly sampled between 1997 and 2000 for visits by pediatric and medicine departments identified higher satisfaction with NP and/or PA interactions than those with physicians, for the overall sample and by specific conditions. The only exception was for diabetes visits to the medicine practices, where the satisfaction was higher for physicians.

Pinkerton, J. \& Bush, H. (2000). Nurse practitioners and physicians: patients' perceived health and satisfaction with care. Journal of the American Academy of Nurse Practitioners, 12(6): 211-217.

Research Question: In managed care settings, how do patients' perception of health and satisfaction compare between physicians and nurse practitioner.

Results: Perceived health and satisfaction were measured in a convenience sample of 160 patients in managed care clinics. There was no statistical difference in these variables between patients cared for by physicians and nurse practitioners.

http://www.wvaprns.com/research/ 
Research | Full Practice Authority for WV APRNs

Page 15 of 16

Morris, McLean, Bishop \& Harlow (1998). A comparison of the evaluation and treatment of cervical dysplasia between nurse practitioners and gynecologists. The Nurse Practitioner, 23(4), 101-114.

Research Question: How do nurse practitioners compare to gynecologists in providing care to women with cervical dysplasia?

Results: Charts of 11 gynecologists and 6 nurse practitioners were retrospectively reviewed for women receiving evaluation and/or treatment of cervical dysplasia. 284 charts from physicians and 478 from NPs were included in the review. Physicians had greater variance in performance compared to NPs. NPs and physician outcomes were generally equivalent, however when there were differences, the NPs were found to have been more consistent with generally accepted medical practice.

Avorn, J., Everitt, D.E., \& Baker, M.W. (1991). The neglected medical history and therapeutic choices for abdominal pain. A nationwide study of 799 physicians and nurses. Archives of Internal Medicine, 151(4), 694-698.

Research Question: How do nurse practitioners compare to physicians when evaluating a patient with a complaint of abdominal pain?

Results: A sample of 501 physicians and 298 NPs participated in a study by responding to a hypothetical scenario regarding epigastric pain in a patient with endoscopic findings of diffuse gastritis. They were able to request additional information before recommending treatment. Adequate history-taking resulted in identifying use of aspirin, coffee, cigarettes, and alcohol, paired with psychosocial stress. Compared to NPs, physicians were more likely to prescribe without seeking relevant history. NPs, in contrast, asked more questions, collect more thorough histories, and were less likely to recommend prescription medication.

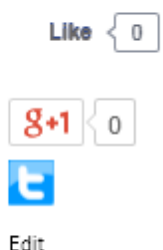

http://www.wvaprns.com/research/ 
Appendix E - Website, con't

State Statutes

State Statutes | Full Practice Authority for WV APRNs

Page 1 of 13

\section{FULL PRACTICE AUTHORITY FOR WV APRNS}

improving healthcare access \& choice

\section{State Statutes}

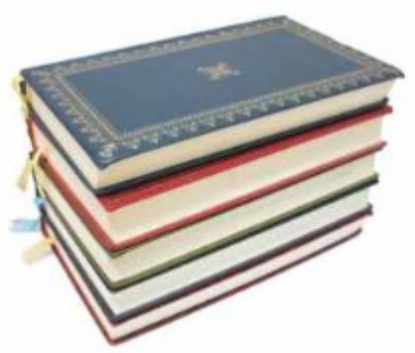

Seventeen states and the District of Columbia have complete independent practice for APRNs. Other states have a range of restrictions from slight to severe. $W$ is one of eight states with the most restrictive laws related to prescribing controlled substances. Below are links to the laws of the states that allow full practice authority for A.PRNs. Share this information with your legislator(s) to show examples of language that has been successfully utilized in full practice states.

\section{Alaska - Regulatory Body: Board of Nursing \\ http:/commerce.alaska.gov/dnn/portals/5/pub/NursingStatutes.pdf (see the following sections) \\ STATUTE}

Sec. 08.68.100. Duties and powers of board

Sec. AS 08.68.850. Definitions.

RULES

12 AAC 44.430. SCOPE OF PRACTICE.

12 AAC 44.440. PRESCRIPTIVE AUTHORITY.

12 AAC 44.445. CONTROLLED SUBSTANCE PRESCRIPTIVE AND DISPENSING AUTHORITY.

\section{Arizona - Regulatory Body: Board of Nursing}

STATUTE

32-1601. Definitions http.//www.azleg.gov/FormatDocument.asp?inDoc=/ars/32/01601.htm\&Title=32\&.DocType=ARS (see 19 Registered Nurse Practitioner) 
32-1606. Powers and duties of board http://ww.azleg.gov/FormatDocumentasp?

inDoc=/ars $/ 32 / 01606$. htm\& Title=32\&DocType=ARS

32-1634.03. Qualifications for certified registered nurse anesthetist; temporary certificate

http://www.azleg.gov/FormatDocument.asp?inDoc=/ars/32/01634-03.htm\&Title=32\&DocType=ARS

32-1634.04. Certified registered nurse anesthetist; scope of practice

http://ww.azleg.gov/FormatDocument asp?inDoc=/ars/32/01634-04.htm\&Title=32\&.DocType=ARS

\section{RULES}

http://www.azbn.gov/Documents/npa/RULES-Effective\%20September\%2010\%202013.pdf (see the following sections in this linked PDF)

ARTICLE 5. ADVANCED PRACTICE REGISTERED NURSING

\section{Colorado - Regulatory Body: Board of Nursing}

\section{STATUTE}

2-38-111.5. Requirements for advanced practice nurse registration-legislative declaration-definition-advanced practice registry

http://cdn.colorado.gov/cs/Satellite?blobcol=urldata\&blobheadernamel=Content-Disposition\& blobheadername2=ContentType\& blobheadervalue1=inline\%3B+filename\%30\%22Colorado+Revised+Statutes+for+Nurses\%2C+effectivve+]uly+1\%

$2 \mathrm{C}+2011 . p d f \% 22 \&$ blobheadervalue2 $=$ application\%

2Fpdf\&blobkey=id\&blobtable=MungoBlobs\&blobwhere $=1251869849129 \&$ ssbinary=true

2-38-1116. Prescriptive authority-advanced practice nurses-rules

http://cdn.colorado.gov/cs/Satellite?blobcol=urldata\&blobheadernamel=Content-Disposition\& blobheadername2=ContentType\& blobheadervalue1=inline\%3B+filename\%30\%22Colorado+Revised+Statutes+for+Nurses\%2C+effectivve+]uly+1\%

2C+2011.pdf\%22\&blobheadervalue2=application\%

2Fpdf\&blobkey=id\&blobtable=MungoBlobs\&blobwhere=1251869849129\&ssbinary=true

12-38-111.8. Professional liability insurance required-advanced practice nurses in independent practice-Rules

http://cdn.colorado.gov/cs/Satellite?blobcol=urldata\&blobheadernamel=Content-Disposition\& blobheadername2=ContentType\& blobheadervalue1=inline\%3B+filename\%30\%22Colorado+Revised+Statutes+for+Nurses\% $2 \mathrm{C}+$ effectivve+]uly+1\% $2 \mathrm{C}+2011 . p d \% 22 \&$ blobheadervalue $2=$ application\%

2Fpdf\&blobkey=id\&blobtable=MungoBlobs\&blobwhere $=1251869849129 \& 55$ binary=true

\section{RULES}

http://www.wvaprns.com/statutes/ 
State Statutes | Full Practice Authority for WV APRNs

Page 3 of 13

3 CCR 716-1 CHAPTER XIV RULES AND REGULATIONS TO REGISTER PROFESSIONAL NURSES QUALIFIED TO ENGAGE IN ADVANCED PRACTICE NURSING

http://cdn.colorado.gov/cs/Satellite?blobcol=urldata\&blobheadernamel=Content-Disposition\&.blobheadername2=ContentType\&blobheadervalue1=inline\%3B+filename\%30\%

22Rules+and+Regulations+to+Register+Professional+Nurses+Qualified+to+Engage+in+Advanced+Practice.pdf\%

$22 \&$ blobheadervalue $2=$ application\%2Fpdf\&blobkey=id\&blobtable=MungoBlobs \&blobwhere $=1251832474222 \& 55$ binary=true

3 CCR 716-1 CHAPTER XV RULES AND REGULATIONS FOR PRESCRIPTIVE AUTHORITY FOR ADVANCED PRACTICE NURSES

http:/cdn.colorado.gov/cs/Satellite?blobcol=urldata\&blobheadername1=Content-Disposition\&.blobheadername2=ContentType\& blobheadervalue1 $=$ inline $\% 3 \mathrm{~B}+$ filename $\% 30 \%$

22 Rules+and+Regulations+for+Prescriptive+Authority+for+Advanced+Practice+Nurses.pdf\% $22 \&$ blobheadervalue $2=a p p l i c a t i o n \%$

2Fpdf\&blobkey=id\&blobtable=MungoBlobs\&blobwhere=1251832461984\&ssbinary=true

3 CCR 716-1 CHAPTER XXI - RULES AND REGULATIONS REGARDING LIABILITY INSURANCE FOR ADVANCED PRACTICE NURSES ENGAGED IN INDEPENDENT PRACTICE

http://cdn.colorado.gov/cs/Satellite?blobcol=urldata\&blobheadername1=Content-Disposition\& blobheadername2=ContentType\&blobheadervalue $1=$ inline $\% 33+$ filename $\% 30 \%$

22Rules+and+Regulations+regarding+Liability+Insurance+for+Advanced+Practice+Nurses+Engaged+in+Independent+Practice.pdf\% 22\&blobheadervalue2=application\%2Fpdf\&blobkey=id\&blobtable=MungoBlobs\&blobwhere=1251832465396\&5sbinary=true

3 CCR 716-1 CHAPTER 22 RULES AND REGULATIONS REGARDING THE DESIGNATION OF AUTHORIZED ENTITIES TO CONDUCT PROFESSIONAL REVIEW OF ADVANCED PRACTICE NURSES

http://cdn.colorado.gov/cs/Satellite?blobcol=urldata\&blobheadernamel=Content-Disposition\& blobheadername2=ContentType\& blobheadervalue $1=i n l i n e \% 3 B+$ filename $\% 30 \%$

22Rules+regarding+Designation+of+Professional+Review+Committees+and+Corresponding+Grant+of+Immunity.pdf\%

$22 \&$ blobheadervalue2=application\%2Fpdf\&blobkey=id\&blobtable=MungoBlobs\&blobwhere $=1251856879649 \&$ ssbinary=true

\section{POLICIES}

30-05: Prescriptive Authority Articulated Plan Compliance and Audit Process

http://cdn.colorado.gov/cs/Satellite?blobcol=urldata\&blobheadername1=Content-Disposition\& blobheadername2=ContentType\& blobheadervalue $1=$ inline\%3 8 +filename $\% 30 \% 22$ verview+of+the+scope+of+practice+of+advanced+practice+nursing $p d f \%$ $22 \&$ blobheadervalue2=application\%2Fpdf\&blobkey=id\&blobtable=MungoBlobs\&blobwhere $=1251849826058 \& 5 s$ binary=true

40-13: Guidelines Regarding Practice Coverage Outside of Normal Office Hours

http://cdn.colorado.gov/cs/Satellite?blobcol=urldata\&blobheadername1=Content-Disposition\& blobheadername2=ContentType\& blobheadervalue1=inline\%3B+filename\%30\%22Policy+40-13\%3A+Advanced+Practice+Nurses+\%28APN\% $29+$ Practice+Coverage+and+Communication+of+Coveragnage+Arrangements+to+Patients.pdf\% $22 \&$ blobheadervalue2=application\%2Fpdf\&.blobkey=id\&blobtable=MungoBlobs\&blobwhere=1251832286119\&.ssbinary=true 
State Statutes | Full Practice Authority for WV APRNs

Page 4 of 13

\author{
District of Columbia - Regulatory Body: Board of Nursing \\ STATUTE \\ http://www.lexisnexis.com/hottopics/dccode/ (see the following sections of this linked code) \\ 3-1202.04. Board of Nursing \\ 3-1205.09. Scope of license, registration, or certification \\ 3-1206 Advanced Registered Nursing; Scope of Practice; Collaboration
}

\author{
Hawaii - Regulatory Body: Board of Nursing \\ STATUTE \\ http://hawaii.gov/dcca/pvl/hrs/hrs_pvl_457.pdf (see the following sections of this linked code) \\ 457-2.7 Advanced practice registered nurse \\ 457-8.5 Advanced practice registered nurse; qualifications; recognition; endorsement; fees; eligibility \\ 457-8.6 Prescriptive authority for advanced practice registered nurses \\ 457-8.8 Advanced practice registered nurses; global signature authority \\ $457-8.5,8.6,8.8)$ \\ RULES \\ http://hawaii.gov/dcca/pvl/har/har_89-c.pdf (see subchapter 14 Advanced Practice Registered Nurses)
}

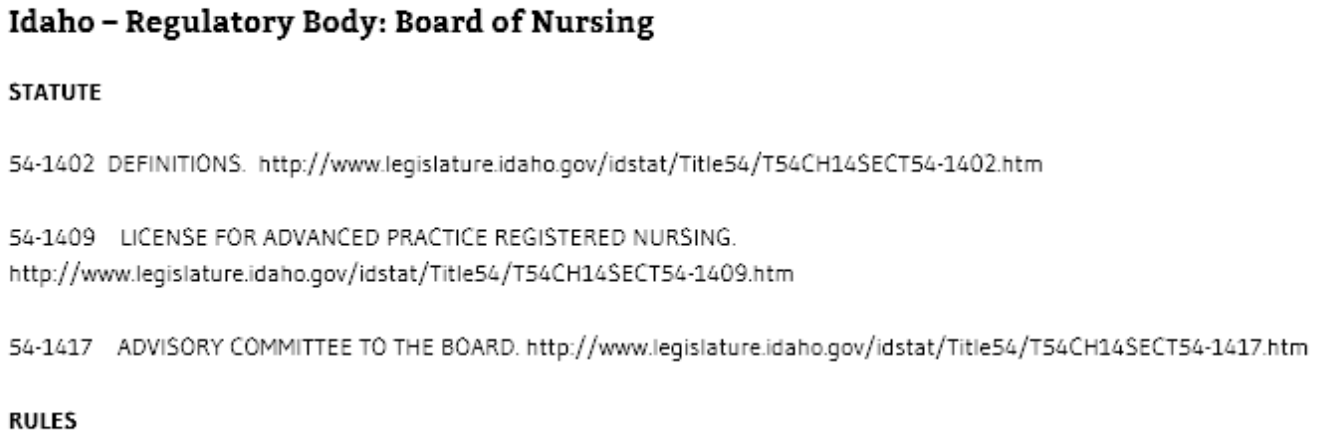


State Statutes | Full Practice Authority for WV APRNs

Page 5 of 13

http:/adminrules.idaho.gov/rules/current/23/0101.pdf (see the following sections)

271. Definitions Related To Advanced Practice Registered Nursing

280. Standards Of Practice For Advanced Practice Registered Nursing

285. Qualifications For Advanced Practice Registered Nurse

290. Application For Licensure - Advanced Practice Registered Nurse

295. Temporary Licensure - Advanced Practice Registered Nurse

300. Renewal Of Advanced Practice Registered Nurse License

301. Reinstatement Of Advanced Practice Registered Nurse License

305. Persons Exempted From Advanced Practice Registered Nursing

License Requirements

306. Disciplinary Enforcement

315. Prescriptive And Dispensing Authorization For Advanced Practice

Registered Nurses

316. Grounds For Discipline Of An Advanced Practice Registered Nurse License

320. Recognition Of National Certifying Organizations For Advanced Practice

Registered Nursing

390. Use Of Titles, Abbreviations, And Designations For The Practice Of Nursing

\section{Iowa - Regulatory Body: Board of Nursing \\ STATUTE}

147.107 Drug dispensing, supplying, and prescribing - limitations http://wwwiowa.gov/nursing/ia_law/lowa\%20Code\% 20Extracts.pdf

http://www.wvaprns.com/statutes/

$3 / 15 / 2014$ 
State Statutes | Full Practice Authority for WV APRNs

Page 6 of 13

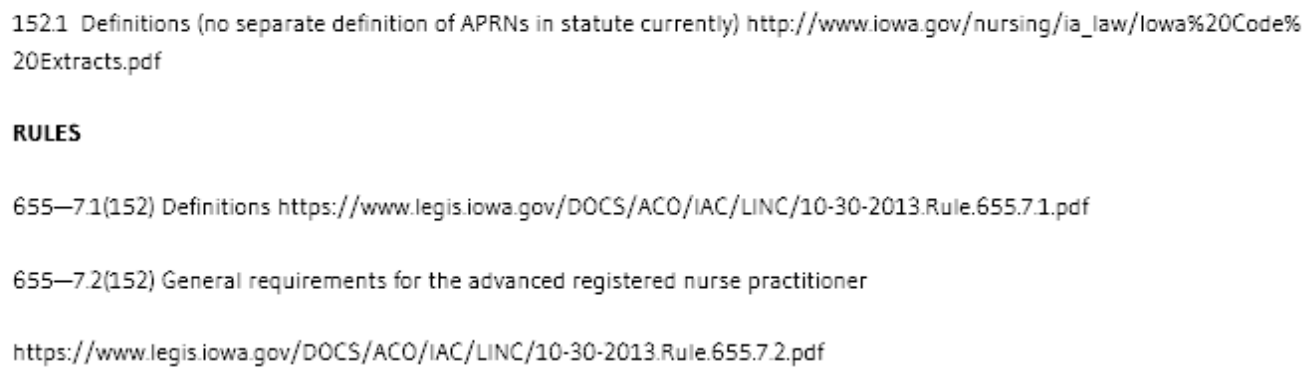

\section{Maine - Regulatory Body: Board of Nursing}

STATUTE

2102. Definitions http//www.mainelegis/ature.org/legis/statutes/32/title32sec2102.html

2201-A. Qualifications for advanced practice registered nurse

http://www.mainelegislature.org/legis/statutes/32/title32sec2201-A.html

RULES

Regulations Relating to Advanced Practice Registered Nursing

http://mainegov/boardofnursing/Administrative/Rules/Chapter\%208.pdf

Use of Controlled Substances For Treatment of Pain

http://mainegov/boardofnursing/Administrative/Rules/Chapter\%2021.pdf

\section{Montana - Regulatory Body: Board of Nursing}

\section{STATUTE}

37-2-101. Definitions. http://eg.mt.gov/bills/mca/37/2/37-2-101.htm

37-8-102. Definitions. http://leg.mt.gov/bills/mca/37/8/37-8-102.htm

37-8-202. Organization - meetings - powers and duties

http://leg.mt.gov/bills/mca/37/8/37-8-202.htm

37-8-409. Advanced practice registered nursing - when professional nurse may practice.

http://leg.mt.gov/bills/mca/37/8/37-8-409.htm

RULES

24.159.14: Advanced Practice Registered Nurses http://www.mtrules.org/gateway/Subchapterhome.asp?scn=24.159.14

http://www.wvaprns.com/statutes/ 
State Statutes | Full Practice Authority for WV APRNs

Page 7 of 13

\section{Nevada - Regulatory Body: Board of Nursing STATUTE}

NRS 632.012 "Advanced practice registered nurse" defined. http://www.leg.state.nv.us/NRS/NRS-632.htm|\#NRS632Sec012

NRS 632.237 Advanced practice registered nurse: Certificate of recognition; regulations. [Effective through ]une 30, 2014.] http://www.leg.state.nv.us/NRS/NRS-632.htm|\#NRS632Sec237

NRS 632.237 Advanced practice registered nurse: Certificate of recognition; practice; regulations; exceptions. [Effective July 1, 2014.] http://www.leg.state.nv.us/NRS/NRS-632.htm|\#NRS632Sec237

NRS 632.238 Advanced practice registered nurse: Requirement to maintain professional liability insurance. http://www.leg.state.nv.us/NRS/NRS-632.htm|\#NRS632Sec238

RULES

PROPOSED REGULATION OF THE STATE BOARD OF NURSING LCB File No. R114-13

http://ww.leg.state.nv.us/Register/2013Register/R114-13l.pdf

NAC 632.020 "Advanced practitioner of nursing" defined

http://www.leg.state.nv.us/NAC/NAC-632.htm|\#NAC632Sec020

NAC 632.2555 Requirements for protocol http//www.leg.state.nv.us/NAC/NAC-632.html\#NAC632Sec2555

NAC 632.256 Records; system of quality assurance. http://www.leg.state.nv.us/NAC/NAC.632.html\#NAC632Sec256

NAC 632.257 Authorization to issue written prescriptions for controlled substances, poisons, dangerous drugs and devices. http://www.leg.state.nv.us/NAC/NAC-632.htm|\#NAC632Sec257

NAC 632.258 Review of application for authority to prescribe controlled substances, poisons, dangerous drugs or devices. http://www.leg.state.nv.us/NAC/NAC-632.html\#NAC632Sec258

NAC 632.259 Controlled substances, poisons, dangerous drugs or devices that may be prescribed. http://www.leg.state.nv.us/NAC/NAC-632.htm|\#NAC632Sec259

NAC 632.2595 Certification to dispense controlled substances, poisons, dangerous drugs and devices. http://ww.leg.state.nv.us/NAC/NAC-632.htm|\#NAC632Sec2595

NAC 632.2597 Certificate of recognition: Issuance in area of practice; specification of area of practice and medical or clinical specialty http://www.leg.state.nv.us/NAC/NAC-632.html\#NAC632Sec2597

NAC 632.260 Qualifications for certificate of recognition; practice by student http://www.leg.state.nv.us/NAC/NAC. 632.html\#NAC632Sec260

NAC 632.265 Certificate of recognition: Submission of application and other documents; temporary certificate. http://www.leg.state.nv.us/NAC/NAC-632.html\#NAC632Sec265

http://www.wvaprns.com/statutes/ 


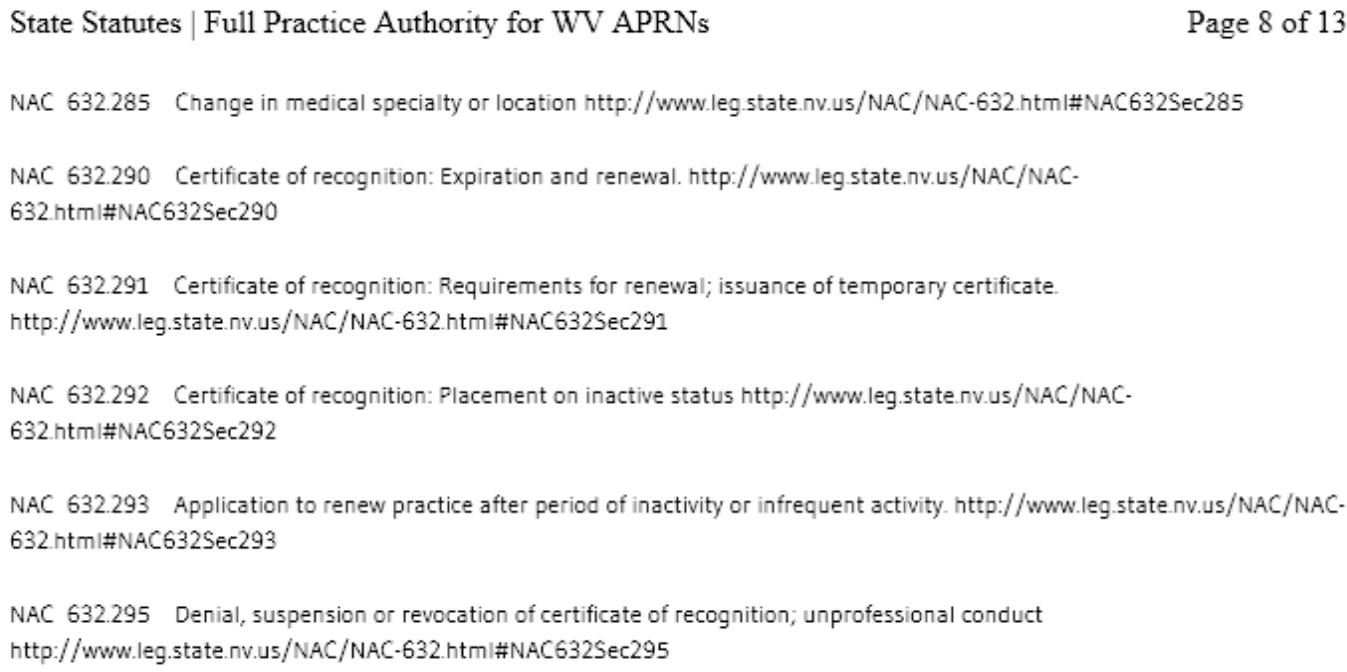

\section{New Hampshire - Regulatory Body: Board of Nursing} STATUTE

326-B:2 Definitions. http://www.gencourt.state.nh.us/rsa/html/ $/ X X / 326-B / 326-B-2 . h t m$

326-B:11 Scope of Practice and Authority; Advanced Practice Registered Nurse http://www.gencourt.state.nh.us/rsa/html/XXX/326-B/326-B-11.htm

326-B:18 Advanced Practice Registered Nurse; Licensure. http //www.gencourt state.nh.us/rsa/html/XXX/326-B/326-B-18.htm RULES

http://www.gencourt.state.nh.us/rules/state_agencies/nur100-800.html (see the following sections) Section Nur 101.01 Advanced Practice Registered Nurse (APRN)

Section Nur 301.03 Advance Practice Registered Nurse (APRN) Licensure Section Nur 302.04 Qualifications for an Initial Advanced Practice Registered Nurse (APRN) License

\section{New Mexico - Regulatory Body: Board of Nursing}

STATUTE

http://nmbon.sks.com/uploads/FileLinks/92034f3e2bed428abaf25331c6745aac/Statues.pdf (see the following sections)

61-3-3. Definitions

61-3-23.2. Certified nurse practitioner; qualifications; practice; examination; endorsement.

http://www.wvaprns.com/statutes/ 
State Statutes | Full Practice Authority for WV APRNs

Page 9 of 13

61-3-23.3. Certified registered nurse anesthetist; qualifications; licensure; practice; endorsement

RULES

http://nmbon.sks.com/uploads/FileLinks/2c3fefa810884b82a8ef5844d87bcc4d/RuleChange16_12_2_NMAC.pdf (see the following sections)

16.12.2.7 DEFINITIONS

16.12.2.10 LICENSURE REQUIREMENTS FOR REGISTERED AND PRACTICAL NURSES

16.12.213 ADVANCED PRACTICE REGISTERED NURSE (APRN) CERTIFIED NURSE PRACTITIONER

PART 9 MANAGEMENT OF CHRONIC PAIN WITH CONTROLLED SUBSTANCES

http://nmbon.sks.com/uploads/FileLinks/2c3fefa810884b82a8ef5844d87bcc4d/RuleChange_16_12_9_NMAC.pdf

\author{
North Dakota - Regulatory Body: Board of Nursing \\ STATUTE \\ http://www.legis.nd.gov/cencode/t43c12-1.pdf?20131109233235 (see the following sections) \\ 43-12.1-02. Definitions \\ 43-12.1-03. License or registration required-Title-Abbreviation \\ 43-12.1-09. Initial licensure and registration \\ RULES \\ 54-01-03-01.De nitions. http://www.legis.nd.gov/information/acdata/pdf/54-01- 03.pdf?20131109233741 \\ CHAPTER 54-05-03.1 ADVANCED PRACTICE REGISTERED NURSE http://wwwlegis.nd.gov/information/acdata/pdf/54-05- \\ 03.1.pdf?20131109234026
}

\title{
Oregon - Regulatory Body: Board of Nursing \\ STATUTE \\ https://www.oregonlegislature.gov/bills_laws/lawsstatutes/2011ors678.html (see the following sections) \\ 678.010 Definitions for ORS 678.010 to 678.410
}

http://www.wvaprns.com/statutes/

$3 / 15 / 2014$ 
678.245 Definitions for ORS 678.245 to 678.285

678.255 Provision of nurse anesthetist services in ambulatory surgical centers

678.265 Ambulatory surgical center oversight of nurse anesthetists

678.275 Provision of nurse anesthetist services I n hospitals

678.375 Nurse practitioners; certificates; prohibitions; authority to sign death certificates; drug prescriptions

678.380 Rules for nurse practitioners; scope

678.390 Authority of nurse practitioner and clinical nurse specialist to write prescriptions or dispense drugs; notice;

requirements; revocation; rules

RULES

DIVISION SO NURSE PRACTITIONERS

http://arcweb.sos.state.or.us/pages/rules/oars_800/oar_851/851_050.html

DIVISION 52 CERTIFIED REGISTERED NURSE ANESTHETISTS

http://arcweb.sos.state.or.us/pages/rules/oars_800/0ar_851/851_052.html

DIVISION 56 CLINICAL NURSE SPECIALIST AND NURSE PRACTITIONER AUTHORITY TO PRESCRIBE AND DISPENSE http:/arcweb.sos.state.or.us/pages/rules/oars_800/oar_851/851_056.htm.

\section{Rhode Island - Regulatory Body: Board of Nursing}

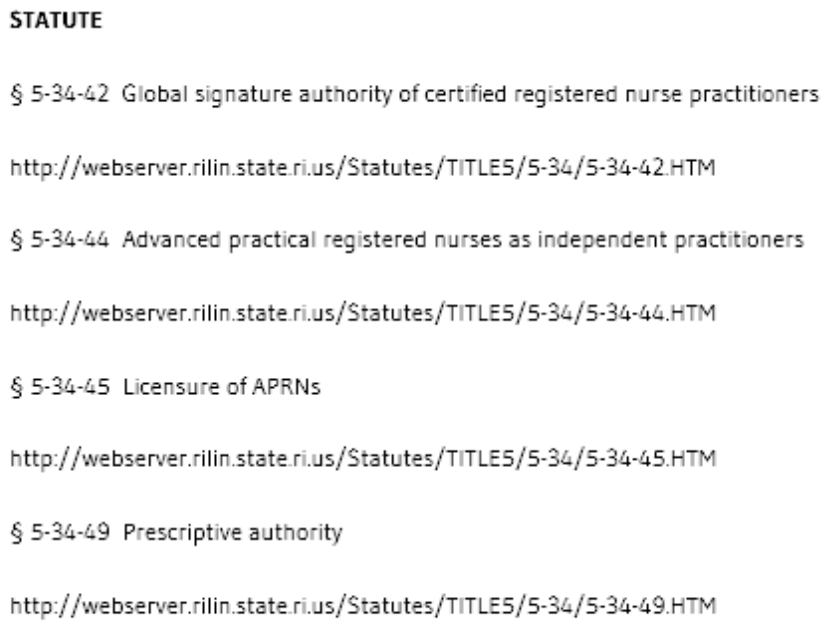

http://www.wvaprns.com/statutes/ 
State Statutes | Full Practice Authority for WV APRNs

Page 11 of 13

REGULATIONS

Section 10.0 Other Requirements for Certified Registered Nurse Practitioners, Certified Registered Nurse

Anesthetists and Psychiatric and Mental Health Clinical Nurse Specialists

http://sos.ri.gov/documents/archives/regdocs/released/pdf/DOH/7006.pdf

\author{
Vermont - Regulatory Body: Board of Nursing \\ STATUTE \\ §1572. Definitions \\ http://www.leg.statevt.us/statutes/fullchapter.cfm?Title=26\&Chapter=028 \\ Sub-Chapter 3: Advanced Practice Registered Nurses \\ http://www.leg.statevt.us/statutes/fullchapter.cfm?Title=26\&.Chapter $=028$
}

\begin{abstract}
ADMINISTRATIVE RULES
See Part 15 Advanced Nursing Practice

http://www.vtprofessionals.org/opr1/nurses/rules/Combined\%20Rules\%20and\%20TOC\%201une\%206\%202011\%20for\% 20web.html
\end{abstract}

\author{
Washington - Regulatory Body: Nursing Commission \\ STATUTE \\ RCW 18.79.050 "Advanced registered nursing practice" defined - Exceptions. \\ http://apps.leg.wa.gov/RCW/default.aspx?cite=18.79.050 \\ RCW 18.79.250 Advanced registered nurse practitioner - Activities allowed. \\ http://apps.leg.wa.gov/RCW/default.aspx?cite=18.79.250
}

http:/www.wvaprns.com/statutes/

$3 / 15 / 2014$ 
RCW 18.79.400 Pain management rules - Criteria for new rules.

http://apps.leg.wa.gov/RCW/default.aspx?cite $=18.79 .400$

RULES

WAC 246-840-300 Advanced registered nurse practitioner (ARNP) scope of practice.

http://apps.leg.wa.gov/WAC/default aspx?cite $=246-840-300$

WAC 246-840-302 ARNP designations, certification and approved certification examinations

http://apps.leg.wa.gov/WAC/default aspx?cite $=246-840-302$

WAC 246-840-400 ARNP prescriptive authority.

http://apps.leg.wa.gov/WAC/default aspx?cite $=246-840-400$

WAC 246-840-420 Authorized prescriptions by ARNP with prescriptive authority

http://apps.leg.wa.gov/WAC/default aspx?cite $=246-840-420$

WAC 246-840-460 Pain management-Intent.

http://apps.leg.wa.gov/WAC/default aspx?cite $=246-840-460$

WAC 246-840-467 Patient evaluation

http://apps.leg.wa.gov/WAC/default aspx?cite $=246-840-467$

WAC 246-840-470 Treatment plan

http:/apps.leg.wa.gov/WAC/default aspx?cite $=246-840-470$

WAC 246-840-475 Written agreement for treatment.

http://apps.leg.wa.gov/WAC/default aspx?cite $=246-840-475$

WAC 246-840-477 Periodic review

http://apps.leg.wa.gov/WAC/default aspx?cite $=246-840-477$

WAC $246-840-480$ Long-acting opioids, including methadone.

http://apps.leg.wa.gov/WAC/default aspx?cite $=246-840-480$

WAC 246-840-485 Consultation-Recommendations and requirements

http://apps.leg.wa.gov/WAC/default aspx?cite $=246-840-485$

http://www.wvaprns.com/statutes/ 
State Statutes | Full Practice Authority for WV APRNs

Page 13 of 13

WAC 246-840-487 Consultation-Exemptions for exigent and special circumstances

http://apps.leg.wa.gov/WAC/default aspx?cite $=246-840-487$

WAC 246-840-490 Consultation-Exemptions for the advanced registered nurse practitioner

http://apps.leg.wa.gov/WAC/default aspx?cite $=246-840-490$

WAC 246-840-493 Pain management specialist

http://apps.leg.wa.gov/WAC/default aspx?cite $=246-840-493$

\section{Wyoming - Regulatory Body: Board of Nursing}

STATUTE (see section 33-21-120. Definitions) http://legisweb.statewy.us/statutes/statutes.aspx?

file $=$ titles $/$ Title33/T33 $\mathrm{CH} 21 . \mathrm{htm}$

RULES

CHAPTER 2 LICENSURE/CERTIFICATION REQUIREMENTS

http://soswy.state.wy.us/Rules/RULES/9365.pdf

CHAPTER 3 SCOPE AND STANDARDS OF NURSING PRACTICE AND CNA ROLE

http://soswy.state.wy.us/Rules/RULES/9366.pdf

LIII: 1

$8 + 1 \longdiv { 0 }$

$\mathrm{E}$

Edit

0 2013 EmbedaedHorizon.Com

http://www.wvaprns.com/statutes/

$3 / 15 / 2014$ 
Appendix E - Website pages, con't

Supporters

Supporters | Full Practice Authority for WV APRNs

Page 1 of 2

\title{
FULL PRACTICE AUTHORITY FOR WV APRNS
}

\author{
improving healthcare access \& choice
}

\section{Supporters}

There are numerous, large, well-respected organizations outside of nursing that ardently support full practice for APRNs. Below are links showing publications from the various organizations that describe why full practice for APRNs is important. Share this information with lawmakers to show how objective and expansive the support for APRN full practice is.

Click Here for More information on support provided by non-nursing organizations

The likelihood of a new law being passed increases with the volume of bill supporters. Please utilize the following links to contact your legislator(s) to ask for their support.

Need help finding your Legislator e-mail address? Please use the following links (which will open in a separate window/tab) to search the maps and locate your legislators. Once identified, copy their email address and return to this window/tab and paste their email in the form below.

- Senate District Maps: http://www.legis.state.wv.us/Districts/maps.cfm

- House District Maps: http://www.legis.state.wv.us/Districts/maps.cfm\#HD01

Please use the e-mail form below to contact your Legislator(s). This e-mail will contain the following text, plus you can provide additional text if desired.

"Hello! I am supportive of West Virginia Advanced Practice Registered Nurses (APRNs) and I would like you to consider supporting SB 212 / HB 4342 (bills to end collaborative agreement and allow APRN's practice to correspond with their educotion and training).

\section{Contact Your Legislator}


Supporters | Full Practice Authority for WV APRNs

Page 2 of 2

Like $\{10$

$8+1\{0$

E

Edit

- 2013 EmbeddedHorizon.Com 
Support Provided by Non-Nursing Organizations | Full Practice Autho... http://www.wvaprns.com/support-provided-by-non-nursing-organiza...

\section{FULL PRACTICE AUTHORITY FOR WV APRNS}

improving healthcare access \& choice

\section{Support Provided by Non-Nursing Organizations}

Many well respected non-nursing organizations have publicly supported having state legislatures retire statutes that limit APRNs from practicing to their full scope of education and training. For example, the Heritage Foundation recently said:

"By removing artificial obstacles that restrict the supply of medical providers, states can expand access to health services across populations while unleashing new competition that can work to reduce costs. States can reform their health care systems by re-examining scope-of-practice laws, which frequently limit the ability of nurse practitioners and other health professionals to care for patients."

Here are some others.

National Governors Association - http://www.nga.org/files/live/sites/NGA/files

/pdf/1212NursePractitionersPaper.pdf

National Conference of State Legislatures -

http://www.ncsl.org/research/health/meeting-the-primary-care-needs-of-rural-america.aspx

Institute of Medicine -

http://books.nap.edu/openbook.php?record_id=12956\&page $=85$

AARP \& Robert Wood Johnson Foundation -

http://campaignforaction.org/campaign-progress/removing-barriers-practice-and-care

Federal Trade Commission -

http://www.ftc.gov/os/2012/09/120907wvatestimony.pdf 
Support Provided by Non-Nursing Organizations |Full Practice Autho... http://www.wvaprns.com/support-provided-by-non-nursing-organiza... World Health Organization http://uww.who.int/bulletin/volumes/91/11/13-118786/en/index.html

Like 0
$8+10$
$\mathrm{~S}$

- 2013 EmbeddedHorizon.Com 
Appendix E - Website pages, con't

Survey

APRNSurvey | Full Practice Authority for WV APRNs

Page 1 of 2

\section{FULL PRACTICE AUTHORITY FOR WV APRNS}

improving healthcare access \& choice

\section{APRNSurvey}

\section{Main}

* Are you a WV APRN or a WV APRN student?

WV APRN $\quad \checkmark$

* Did you contact your legislator last year regarding supporting SB 379 [bill to end collaborative agreement]?

Yes $\checkmark$

* If you did contact your legislator(s) did you provide documentation supporting why they should support SB 379 ? (ie: reference to research on APRN safety, IOM "Future of Nursing Report", etc.)?

Yes $\quad \checkmark$

* Have you, or do you intend to, contact your legislator(s) in support of the bill in this 2014 session to end the collaborative agreement requirement for APRNs (SB 212)?

Yes V

* If you have, or intend to, contact your legislator(s) have you, or do you intend to, share a link to this website that provides documentation showing APRNs are safe, quality providers autonomously?

Yes $\quad \checkmark$

* If you have, or intend to, contact your legislator(s) did this website influence you to make such contact? 
Page 1 out of 1

$$
\text { Lllke } 4
$$

$$
8 + 1 \longdiv { 0 }
$$

$\mathrm{E}$

Edit 
Appendix E - Website pages, con't

Contact page

Contact Us | Full Practice Authority for WV APRNs

http://www.wvaprns.com/contact-us/

\section{FULL PRACTICE AUTHORITY FOR WV APRNS}

improving healthcare access \& choice

\section{Contact Us}

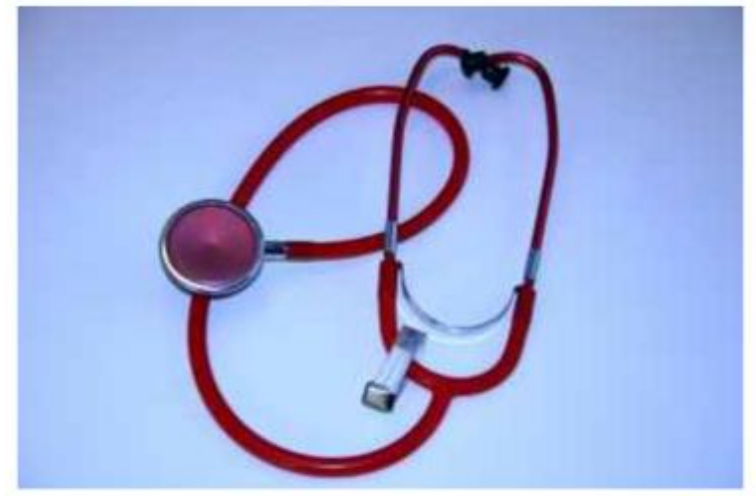

Fill out the form below for more information on how you can help APRNs gain full prescriptive authority.

Name: *

Address:

Email Address: *

Phone number:

Subject: *

Message: * 